\title{
The North Pennine batholith (Weardale Granite) of northern England - new data on its age and form
}

\author{
G. S. KimBell ${ }^{1}$, B. YounG ${ }^{2}$, D. Millward ${ }^{3} \&$ Crowley, Q.G. ${ }^{4 *}$ \\ ${ }^{1}$ British Geological Survey, Kingsley Dunham Centre, Keyworth, Nottingham NG12 5 GG (email: \\ gsk@bgs.ac.uk) \\ ${ }^{2}$ Department of Earth Sciences, Science Laboratories, South Road, Durham DH1 3LE \\ ${ }^{3}$ British Geological Survey, Murchison House, West Mains Road, Edinburgh, EH9 3LA \\ ${ }^{4}$ Department of Geology, School of Natural Sciences, Trinity College, Dublin 2, Ireland \\ (* formerly: NERC Isotope Geosciences Laboratory, Kingsley Dunham Centre, Keyworth, Nottingham NG12 \\ $5 G G)$
}

SUMMARY: A three-dimensional gravity model of the North Pennine batholith is interpreted to indicate that it comprises five contiguous steep-sided plutons. The North Pennine batholith was previously referred to as the Weardale Granite, but this term is now restricted to the largest, most central pluton, which was proved by the Rookhope Borehole in 1961. The surrounding plutons are the Tynehead and Scordale plutons in the west, and the Rowlands Gill and Cornsay plutons in the east. A new U-Pb zircon age of $399.3 \pm 0.7 \mathrm{Ma}$ demonstrates an unequivocal Early Devonian (Emsian) age of emplacement for the Weardale Pluton. The similarity of the forms of the four unsampled plutons to the body beneath Rookhope, and to other Devonian granites in Northern England, strongly suggests that they are also of Devonian age. Seismic reflection evidence supports a contrast between relatively deep-seated Devonian granites and tabular Ordovician granites in northern England. The most conspicuous magnetic anomalies over the North Pennine batholith are associated with the Early Permian Great Whin Sill, but there is also evidence of magnetized basement rocks or denser magnetic intrusive phases on the flanks of the non-magnetic, low density plutons. A long-wavelength magnetic low can be explained in part by the granite puncturing a deep magnetic basement, although the demagnetized zone may extend beneath the batholith. A spatial correlation between the vein systems in the Northern Pennine Orefield and the form of the batholith suggests that the granite masses played a significant role in focussing mineralizing fluids into the overlying Carboniferous rocks. The highest temperature mineralization occurs over the Weardale and Tynehead plutons, where there is also the clearest evidence for the channelling of mineralizing fluids through the batholith. The other plutons are generally associated with a lower intensity of mineralization, which occurs on 
their flanks rather than above their roofs. The Rookhope and Tynehead areas may therefore mark the location of convective 'chimneys' which were important in focussing the fluid circulation responsible for the mineralization. The coincidence of the 'chimney' zones with the minimum of the long wavelength magnetic low suggests that the hydrothermal system may also have played a role in modifying crustal magnetization.

[End of Summary]

The existence of a granite body concealed beneath the Alston Block in the north Pennines was first suggested on the basis of the zoned distribution of constituent minerals within the area's hydrothermal veins and related deposits (Dunham 1934, 1948). A central zone is characterized by high temperature mineral assemblages in which fluorite is prevalent (Fig. 1). This zone is surrounded by lower temperature mineralization dominated by barium minerals. Comparison with the south-west England orefields led Dunham (1934) to speculate that a concealed, 'Variscan'-age granite 'batholith or stock' beneath the orefield centre generated the mineralization. Subsequently, strong support for the presence of a low-density granitic body was provided by gravity surveys (Bott \& Masson Smith 1953, 1957a; Bott 1967). These were interpreted to show a single mass with five cupolas (Fig. 2).

A borehole drilled at Rookhope in Weardale [NY 9374 4278] in 1960-61 proved granite beneath the Carboniferous sedimentary cover at a depth of $390.5 \mathrm{~m}$ (70 m below sea level) (Fig. 1; Dunham et al. 1961; Dunham et al. 1965). However, a weathered top to the granite indicated that it could not have been emplaced in Variscan times. A second proving was made in 2004 at Eastgate in Weardale [NY 9387 3821], in which granite was reached at $271.5 \mathrm{~m}$ below the surface ( $20 \mathrm{~m}$ below sea level) (Manning et al. 2007).

The granite was probably emplaced into cleaved mudstones of the Skiddaw Group, based on the presence of these rocks in the Cross Fell and Teesdale inliers, in the Wrentnall Shaft at Cowgreen Mine [NY 8105 3053], in the Allenheads No 1 Borehole [NY 8604 4539] (Dunham 1990) and of hornfelsed slates from the Roddymoor Borehole [NZ 1513 3634] at Crook (Woolacott 1923). Garnet in rocks in the last borehole, and incipient contact metamorphism of Skiddaw Group rocks at outcrop within the Teesdale Inlier at Pencil Mill [NY 8490 2956] (Robinson 1970; Burgess \& Holliday 1979) are probable evidence for the thermal aureole surrounding the granite.

At the centre of the geological development of the region is the Alston Block, a horst, bound to the north, south and west respectively by the Stublick-Ninety Fathom, Close House- 
Lunedale, and Pennine fault zones (Fig. 3). This structure, along with the SolwayNorthumberland Basin to the north and the Stainmore Basin to the south, was initiated in early Carboniferous time in response to north-south extension above the Iapetus Convergence Zone (Chadwick et al. 1995). As a consequence of the relative strength and buoyancy given to the Alston Block by the concealed batholith, the succession of Carboniferous sedimentary rocks overlying it is comparatively thin, consisting dominantly of cyclothemic sequences of limestone, mudstone and sandstone. In Early Permian time, dolerite sills of the Whin Sill-swarm (Gillespie et al. 2008) and their dyke feeders were emplaced (Liss et al. 2004). An extensive suite of mineral veins and associated replacement deposits in adjoining carbonate wallrocks, hosted by a conjugate set of mainly normal faults was emplaced soon after intrusion of the Great Whin Sill (Young et al., 1985; Dunham 1990).

This paper describes the geophysics of the granitic mass beneath the Alston Block in the north Pennines; this mass, previously identified as the Weardale Granite (e.g. Bott 1967), is here referred to as the North Pennine batholith (Stone et al. 2010), comprising five distinct plutons. The term 'Weardale Granite Pluton', or simply 'Weardale Pluton', is applied in a restricted sense to the large central pluton of the batholith. We present a new, high-precision $\mathrm{U}-\mathrm{Pb}$ zircon Devonian age for this pluton. Three-dimensional gravity modelling is used to investigate the geometry of the batholith, and we consider the results of seismic reflection surveys which provide further insights into its structure and the nature of the underlying crust. Magnetic surveys reveal relatively shallow magnetization contrasts around the pluton margins and a deeper magnetic effect that is apparently associated with the batholith. The relationship with mineralization in the Northern Pennine Orefield is reassessed in the light of this evidence, and areas where the mineralizing fluids have been channelled through granite plutons are distinguished from others where such fluids appear to have been directed along their flanks.

\section{GEOPHYSICAL EVIDENCE}

\subsection{Gravity modelling}

In order to model the three-dimensional form of the granite, it was first necessary to account for the gravitational effect of other rocks, in particular the variable thickness of Carboniferous and younger sedimentary cover above the Caledonian basement (Fig. 3). This has been done using the interpretation by Chadwick et al. (1995) of the structure of the cover sequence, which was based on seismic reflection data. The stratigraphical classification used (Table 1) 
has recently been revised following Waters et al. (2007) and a comparison between the two schemes can be found in Stone et al. (2010). The densities assumed in the modelling (Table 1) were derived from the analysis of geophysical well logs in the region (Kimbell et al. 2006).

The basement density employed $\left(2.78 \mathrm{Mg} / \mathrm{m}^{3}\right)$ is appropriate for Lower Ordovician metasedimentary rocks of the Skiddaw Group, but is higher than the estimated densities for the Borrowdale Volcanic Group and the Silurian strata which crop out in the southern Lake District (Bott 1974, 1978; Lee 1984, 1986, 1989). This is a reasonable assumption for the basement of the Alston Block, based on the evidence cited above. However, lower density Lower Palaeozoic rocks also crop out in the Pennine Fault Zone and may underlie the adjacent basins, and their omission may lead to some distortion of the model.

The gravity effect of the sedimentary sequence was calculated using the Gmod program (Dabek \& Williamson 1999), which uses fast wavenumber-domain computation routines (Parker 1972). The cover sequence interfaces mapped by Chadwick et al. (1995) were represented by regular grids with a $1 \mathrm{~km}$ node spacing, and the densities assumed for the units between these interfaces were as tabulated above. The computations covered a larger area than shown in Figure 3 and were referred to a level surface at $1 \mathrm{~km}$ above the sea-level datum, just above the highest topography. The observed anomalies were continued to the same level from the irregular observation surface using the equivalent source method (e.g. Blakely 1995, p. 320). Subtraction of the calculated gravity anomalies from the continued, observed field leaves the stripped field shown in Figure 4a. A further regional or background field was removed, which accounts for long wavelength gravity variations assumed to be generated by deep structure, lying beneath the modelled volume. This has a minimum along an axis crossing the western side of the Alston Block and increases gradually to west and east (Fig. 4b). Subtraction of the regional field from the stripped field leaves the gravity field shown in Figure 4c, which was used as the input for modelling the form of the batholith.

The granite mass was assigned a density of $2.63 \mathrm{Mg} / \mathrm{m}^{3}$ (i.e. a contrast of $-0.15 \mathrm{Mg} / \mathrm{m}^{3}$ with basement), based on the measured density of samples from the Rookhope Borehole (Bott 1967). Its base was set at $9 \mathrm{~km}$ and the form of the upper surface modified iteratively in order to minimize the difference between the calculated and input gravity fields, with the constraint that this surface could not lie at shallower depth than the top of the Caledonian basement (Fig. 3). Both wavenumber-domain (Oldenburg 1974) and spatial-domain (Rollin 1988) 
optimization methods were tested, but the latter proved more stable and is the basis for the model presented here (Fig. 5). The depth to the base of the granite mass was chosen as the result of a series of trials, and meets the dual requirements of predicting a granite subcrop at the basement surface where this is proved by the Rookhope and Eastgate boreholes, and generating a calculated field (Fig. 4d) that provides a good match to the observations. The root-mean-squared misfit between observed and calculated anomalies in the area shown is 1.35 mGal. The largest discrepancies occur in the south-eastern corner and along the western edge of the area, and are probably related to limitations in the cover sequence model rather than to the granite. Residual anomalies are less than $2 \mathrm{mGal}$ throughout the area underlain by the main granite body.

The seismic surveys discussed in the following section indicate a change in crustal reflectivity beneath the granite at a depth of approximately $12 \mathrm{~km}$. Further gravity modelling was undertaken to test the hypothesis that this reflectivity change is associated with the base of the intrusive body. If the granite base is set at this depth and a density contrast of $-0.15 \mathrm{Mg} / \mathrm{m}^{3}$ is retained, the predicted top of the granite lies at a depth of more than $1 \mathrm{~km}$ below the pre-Carboniferous basement surface at the sites of the Rookhope and Eastgate boreholes. The density contrast between granite and country rock was modified in order to produce a solution that was more compatible with these provings. The appropriate contrast lies in the range -0.12 to $-0.13 \mathrm{Mg} / \mathrm{m}^{3}$ and Figure 6 illustrates the case in which a value of $-0.125 \mathrm{Mg} / \mathrm{m}^{3}$ is assumed. The root-mean-squared residual anomaly in this case was $1.58 \mathrm{mGal}$.

The two models presented here (Figs 5 and 6), and earlier three-dimensional modelling of the eastern side of the granite by Evans et al. (1988), all predict similar geometries. The whole mass has a complex shape, underlying an area of about 60 by $30 \mathrm{~km}$. This shape does not readily fit with that of most single plutons, a body of igneous rock with a generally simple, regular margin (Gillespie et al. 2008). The five elevated areas were interpreted by Bott \& Masson Smith (1953, 1957a) and Bott (1967) as cupolas above a single mass, but our modelling emphasises the clefts between these highs. Indeed, the alternative model (Fig. 6) further accentuates this separation. Therefore, we contend that this complexity of shape is best explained if the granite mass beneath the Alston Block is considered to comprise five contiguous, broadly conical, plutons, and these are here referred to as the Weardale, Tynehead, Scordale, Rowlands Gill and Cornsay granite plutons (Fig. 5; Stone et al. 2010). The informal term North Pennine batholith is used to refer collectively to the contiguous 
plutons. Our proposals are in line with those of Gillespie et al. (2008) for formally classifying units of igneous rock.

The influence of changing the assumptions about the depth to the base of the intrusion are most noticeable in the steepness of the flanks of the plutons and in the depth to granite in the areas between them. A modelled apparent granite culmination just to the south-west of the Scordale Pluton is likely to be an artefact due to inaccuracies in removing the gravity effect of the sedimentary cover in this part of the Vale of Eden Basin, where there was little information to constrain the initial cover-sequence interpretation (D W Holliday, written communication 2010).

\subsection{Seismic surveys}

BGS conducted vibroseis seismic reflection surveys in the region in 1986, as part of an investigation of the geothermal potential of the UK funded by the Department of Energy (Evans et al. 1988). The surveys extended from the outskirts of Newcastle-upon-Tyne to the Rookhope Borehole (Fig. 5). Long (12 s) records were acquired, potentially allowing imaging to the depth of the Moho. Data quality was poor in areas where urban development and traffic noise impeded surveying, and where the seismic signal was attenuated and scattered by unconsolidated superficial deposits and old coal workings (Evans et al. 1988; Kimbell et al. 1989). Very good data quality was achieved where noise levels were low and seismic penetration was good. Figure 7 shows a section of north-south line BGS86-03 where an exceptionally clear image of the crust down to the Moho was achieved. The rapid drop-off in data quality on either side of this window illustrates the influence of near-surface conditions on the quality of deep seismic imaging.

The upper part of the section in Figure 7, above about $0.5 \mathrm{~s}$ twtt (two-way travel time), is dominated by the near-horizontal reflectors associated with the Carboniferous cover sequence. The broad 'dome' defined by these reflectors along the full length of line BGS8603 (Fig. 8) is accentuated by the trajectory (convex westward) of the seismic profile across the east-dipping Alston Block sequence. The top basement surface is constrained by the results from the Roddymoor Borehole, which lies close to the profile. It is thus evident that the clear reflections at 1 to $2 \mathrm{~s}$ twtt are due to acoustic impedance contrasts within the underlying basement. They lie at shallowest depth between CDPs (common depth points) 800 and 900, which coincide with the top of a saddle in the interpreted top granite surface lying between the Rookhope and Cornsay plutons (Fig. 5). A relationship between the reflections 
and the top of the concealed granite thus appears likely (Evans et al. 1988; Kimbell et al. 2006). Comparison with the granite geometry from the 3D gravity modelling (Fig. 8) supports this interpretation, with the model with a shallower base providing a somewhat better fit. The correspondence is not exact, which may be in part because of the limitations of 2D seismic migration and depth conversion over a 3D structure. Geological complexity may also be a factor, as the reflection signature is not that of a simple granite-country rock interface. The more complex (multi-cycle) waveform may indicate interleaving of granite and country rock above the main part of the intrusion and/or the intrusion may have domed or truncated pre-existing basement reflectivity. Some reflections may also have been enhanced by a focusing effect associated with the local 3D geometry.

The seismic reflection section along line BGS86-04 (Fig. 9) also indicates an association between the reflectivity pattern and the presence of the underlying granite. On that line there are only a few diffuse reflectors that might be directly associated with the upper surface of the granite, but there is a more general correspondence between higher reflectivity and a wedge of Lower Palaeozoic rocks predicted by the gravity modelling to overlie the granite roof at the eastern end of the profile. Again, the gravity model with a shallower base appears to match the seismic data better.

Although the interior of the granite mass is not highly reflective, there is evidence of coherent reflections from within it that indicate that it is not structureless. Reflections were detected at 0.2 - $3 \mathrm{~s}$ twtt beneath the western part line BGS86-04 where gravity modelling indicates that granite lies immediately beneath the Carboniferous sedimentary cover (Fig. 9). The reflectors that project up towards the basement surface at around CDP 850 lie on the trend of the fault which acts as the host to the Hunstanworth White Vein (WV in Fig. 1), suggesting that they are due to acoustic property contrasts related to the extension of this fracturing into the granite mass. The reflectors that extend up to top basement at around CDP 950 do not coincide with a mapped fault, but they were also detected on line BGS86-05, allowing their dip to be estimated at 55-60 $0^{\circ}$ towards the NE (Evans et al. 1988). If projected towards the south-east they can be correlated with a zone of fracturing with the same trend encountered in the Derwent-Wear section of the Kielder aqueduct system (Dunham 1990, p. 176). There is also evidence of more diffuse, flat-lying reflectivity within the granite which might be compositional in origin (Fig. 9).

Distinct near-horizontal reflectors occur below $4.3 \mathrm{~s}$ twtt on line BGS86-03 (Fig. 7). These are detected on BGS86-04 where it intersects with BGS86-03, and can be traced eastwards 
towards the centre of the granite mass where the onset of the reflectivity occurs somewhat later, at about $4.7 \mathrm{~s}$ twtt (Fig. 9). This apparent eastward deepening of the mid-crustal reflectors may be partly offset by velocity variation in the overlying rocks, since Bott et al. (1984) estimated a lower velocity (about $5.4 \mathrm{~km} / \mathrm{s}$ ) for granite basement than for basement elsewhere $(5.8 \mathrm{~km} / \mathrm{s})$ from the results of seismic refraction surveys. Adopting these velocities, and assuming a velocity of $4 \mathrm{~km} / \mathrm{s}$ for the overlying Carboniferous rocks, the onset of the mid-crustal reflectivity is estimated to lie at a depth of about $11.9 \mathrm{~km}$ beneath the wedge of Lower Palaeozoic rocks on the eastern side of line BGS86-04 and about $12.5 \mathrm{~km}$ beneath the western side of this line. This change in seismic character could be an expression of the base of the granite mass, as has been explored in the gravity modelling, or a more widespread phenomenon (Conrad discontinuity?) the existence of which in this area sets a maximum depth for the base of the granite mass rather than a direct indication of it.

There is a zone of very prominent, high-amplitude reflections between about $8 \mathrm{~s}$ and $10 \mathrm{~s}$ twtt (about 24 to $30 \mathrm{~km}$ ) beneath line BGS86-03 (Fig. 7). Similar reflectors were detected beneath much of line BGS86-04 and parts of line BGS86-05 (Evans et al. 1988; see also Klemperer \& Hobbs 1991; Ward et al. 1991). On the basis of comparison between normal incidence and wide-angle seismic surveys elsewhere, the seismic Moho is usually interpreted to lie at the base of the highly reflective layer. Lower crustal reflectivity has been identified in many locations on the UK continental shelf (primarily by the BIRPS experiments; Klemperer \& Hobbs 1991; Snyder \& Hobbs 1999) and is thus not necessarily a particular characteristic of the crust beneath this region, but its presence does place some constraints on the nature of the granite mass. If the deep crustal reflectivity predates emplacement of the batholith, which is implied by interpretations that relate changes in this reflectivity to the collisional events that preceded its intrusion (e.g. Soper et al. 1992), it follows that intrusion of the granite has not involved widespread destruction of the reflective fabric. Local modifications to the observed reflection pattern may occur as a result of conduits associated with granite emplacement, but are difficult to identify with current data because of lateral changes in data quality due to near-surface conditions.

\subsection{Magnetic surveys}

Figure 10 illustrates the magnetic signatures over the North Pennine batholith, based on regional aeromagnetic data acquired on N-S flight lines with a line spacing of $2 \mathrm{~km}$. The reduced-to-pole magnetic field (Fig. 10a) has been split into long- and short-wavelength components by upward continuation. Reduction to the pole transforms a magnetic anomaly 
into that which would occur if both the magnetization of the body and the field direction were vertical (as at the magnetic north pole), thereby removing the typical skewness of magnetic anomalies and relating them more obviously to subsurface sources. The long-wavelength component (Fig. 10b) is dominated by a magnetic low which has a close spatial correlation with the modelled granite batholith. Bott \& Masson Smith (1957b) attributed this to the magnetization contrast between the granite (which has a low magnetic susceptibility) and the relatively magnetic basement it is intruded into, and ascribed a slight south-eastward displacement of the magnetic feature relative to the gravitational feature to the influence of remanent magnetization. The modelling of Kimbell et al. (2006) indicated that the top of the magnetic basement lies at greater depth than the Caledonian basement surface shown in Figure 3, and they identified it to be part of the Precambrian (Avalonian) magnetic crystalline basement that underlies much of northern and central England (see also Kimbell \& Quirk 1999). The magnetic modelling suggested that, although the demagnetized zone coincides spatially with the granite, it extends to greater depth (down to 16-20 km) (Kimbell \& Quirk 1999; Kimbell et al. 2006). By invoking a degree of vertical mismatch between the low density batholith and the demagnetized zone it was possible to explain the observed anomaly without invoking remanent magnetization. Kimbell \& Stone (1995) argued that such magnetization is unlikely to be sufficiently strong and consistent within the Precambrian crystalline basement beneath this region to divert its total magnetization vector significantly from the direction of the Earth's present field.

Much of the shorter wavelength magnetic variation in the area (Fig. 10c) is associated with the Great Whin Sill. This has a strong remanent magnetization directed southwards at low angles, which explains the magnetic high that marks its northern margin and the magnetic low at its concealed southern margin at the Lunedale Fault (Fig. 10c; Cornwell \& Evans 1986). Elsewhere, magnetic anomalies are associated with offsets and alteration (to nonmagnetic 'White Whin') at faults and veins. For example, it is possible to correlate magnetic lineaments with the Hunstanworth White, Rookhope Red and Slitt veins (Fig. 10c). Figure 10 is based on low-resolution aeromagnetic data; higher resolution surveys towards the northwest have been used to extract much more structural detail and drilling has been used to confirm the sources of the anomalies (Cornwell \& Evans 1986). The Palaeogene Cleveland Dyke (Macdonald et al., 1988) extends across the southern part of the area and has been mapped at outcrop in its south-east corner (Fig. 1). Its magnetic signature, however, is difficult to discern amongst those associated with the Great Whin Sill. 
The residual magnetic image (Fig. 10c) also highlights anomalies which appear to be due to magnetic sources adjacent to the flanks of the granite plutons. The most prominent of these is the Blanchland anomaly on the northern flank of the Weardale Pluton, which might be due to metamorphic effects adjacent to the granite, to a magnetic intrusive body or to Ordovician magnetic volcanic rocks (Bott \& Masson-Smith 1957b; Bott 1967; Evans et al. 1988). Figure 10c suggests that analogues for this anomaly may occur on the flanks of all the other plutons. The roof of each of the smaller plutons is associated with a local magnetic low, and this is compatible with them extending up to the basement surface. There is even some corroboration of the approximately triangular form for the Scordale Pluton suggested by the gravity modelling.

A residual magnetic anomaly on the southern flank of the Cornsay Pluton might reconcile an apparent conflict between the gravity modelling results and evidence from the Roddymoor Borehole. There is a perpendicular distance of about $3 \mathrm{~km}$ between the modelled top of the granite and the basement sampled by that borehole, but the strength of the metamorphism observed suggests a much closer proximity. A possible explanation is that there is a relatively dense and moderately magnetic component of the pluton that extends towards the borehole.

\subsection{Heat flow}

A terrestrial heat flow of $92 \mathrm{mWm}^{-2}$ at the Rookhope Borehole site was determined by Bott et al. (1972) using temperature measurements made in 1964. The temperature profile was remeasured in 1976 and had changed very little, providing a similar heat flow estimate of $95 \mathrm{mWm}^{-2}$ (England et al. 1980). This is significantly higher than the typical 'background' heat flow in this part of the UK of 50-60 $\mathrm{mWm}^{-2}$ (Bott et al. 1972; Gebski et al. 1987), a fact which can be attributed to the elevated concentrations of heat-producing radiogenic elements within the granite, providing these concentrations do not decline rapidly with depth. Measurements on granite samples from the Rookhope Borehole have yielded heat production estimates of $4.6 \mu \mathrm{Wm}^{-3}$ (Bott et al. 1972) and $3.7 \mu \mathrm{Wm}^{-3}$ (Lee et al. 1987). The calculated radiothermal heat production rates from unaltered granite in the Eastgate Borehole average $4.1 \mu \mathrm{Wm}^{-3}$ (Manning et al. 2007). The combined effect on heat flow of refraction of heat into the pluton (because of its relatively high thermal conductivity) and lateral conduction of heat outwards from the pluton is likely to be small (England et al. 1980).

A heat flow of $100 \mathrm{mWm}^{-2}$ was measured in a borehole above the centre of the Rowlands Gill Pluton (Gebski et al. 1987; Evans et al. 1988). This measurement was made within the 
overlying Carboniferous sedimentary rocks, so is more susceptible to distortion as a result of water movement than the Rookhope measurement, but nonetheless provides some corroboration of the presence of a radiogenic granite.

Relatively high heat flows have been measured in the Woodland Borehole $\left(96 \mathrm{mWm}^{-2}\right)$ on the southern side of the Alston Block (Fig. 1) and Longhorsely Borehole $\left(92 \mathrm{mWm}^{-2}\right)$ in the Northumberland Basin, although these have been attributed to upward groundwater movement in the Butterknowle and Causey Park faults respectively (Bott et al. 1972; Gebski et al. 1987). A heat flow of $85 \mathrm{mWm}^{-2}$ has been estimated from measurements in Dufton and Newbiggin boreholes in the Vale of Eden Basin (Figs. 1, 5; Gebski et al. 1987). These are in a basin containing major Permo-Triassic aquifers and close to the Pennine Fault Zone so there is again the likelihood of a hydrogeological influence, but their proximity to the modelled Scordale Pluton may also be relevant.

Indirect evidence for the thermal influence of the granite mass is provided by the increased rank (reduction in volatile content) in coal seams overlying its eastern side (Trotter 1954; Bott 1967; Evans et al. 1988). Farther west, Creaney (1980) used petrographic and vitrinite reflectance data to identify a spatial relationship between high pre-Whin Sill palaeotemperature and the location of Weardale and Tynehead plutons.

\section{GEOLOGICAL AND GEOCHRONOLOGICAL EVIDENCE}

\subsection{Borehole sampling}

The granite sampled by the Rookhope Borehole is typically a white to pale grey aphyric rock composed of albite, potassium feldspar, quartz, muscovite and biotite, with accessory magnetite-ilmenite, zircon and monazite. Pegmatitic and aplitic segregations occur locally, together with a few tourmaline veins. A conspicuous, low-lying foliation, marked by mica and quartz 'eyes', has been interpreted as an igneous fabric (Dunham et al. 1965; Holland 1967). The Eastgate Borehole was not cored, but Manning et al. (2007) described the granite cuttings obtained as closely resembling the rock cored at Rookhope.

There have been several attempts to obtain meaningful radiometric ages from the granite sampled at Rookhope. Dodson \& Moorbath (1961) produced a weighted mean muscovite RbSr and K-Ar age of $362 \pm 6 \mathrm{Ma}$. It was noted that this was considerably younger than the age estimates for the Shap and Skiddaw granites known at the time. Subsequently, Fitch \& Millar (1965) presented K-Ar muscovite ages from 392 to 359 Ma and a K-Ar chlorite age of $255 \pm$ 
$12 \mathrm{Ma}$, none of which were taken to represent actual emplacement ages. Holland \& Lambert (1970) published a $\mathrm{Rb}-\mathrm{Sr}$ whole-rock isochron age of $410 \pm 10 \mathrm{Ma}$ which was tentatively interpreted to represent closure of the $\mathrm{Rb}$-Sr system related to crystallization of the granite. Most recently, Selby et al. (2008) produced a single Re-Os age of $398 \pm 1.6 \mathrm{Ma}$ from molybdenite in a pegmatite vein in the granite and this has been taken as an estimate of the minimum age of granite emplacement.

\subsection{A new $\mathrm{U}-\mathrm{Pb}$ zircon age for the Weardale Granite Pluton}

\subsubsection{Analytical Techniques}

Zircon fractions were analysed by Isotope Dilution Thermal Ionization Mass Spectrometry (ID-TIMS) at the NERC Isotope Geosciences Laboratory (NIGL). Analytical procedures are as described in Noble et al. (1993). A c. $5 \mathrm{~kg}$ sample was taken from a depth of $418 \mathrm{~m}$ in the Rookhope Borehole. Zircon crystals were separated from $<355 \mu \mathrm{m}$ whole-rock fraction using standard vibrating-table, specific gravity and magnetic techniques. Crystal fractions for analysis were picked by hand under a binocular microscope. A bulk zircon fraction was annealed at $800^{\circ} \mathrm{C}$ in quartz glass beakers for 48 hours. The zircon crystals were

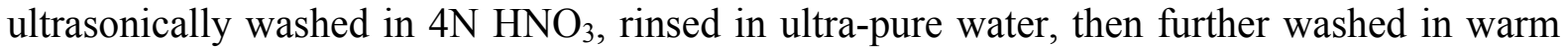
$4 \mathrm{~N} \mathrm{HNO}_{3}$ prior to rinsing with distilled water to remove surface contamination. The annealed, cleaned, bulk zircon fraction was then chemically abraded in $200 \mu 129 \mathrm{~N} \mathrm{HF}$ and $20 \mu 18 \mathrm{~N} \mathrm{HNO}_{3}$ at $120^{\circ} \mathrm{C}$ for 12 hours following a modified chemical abrasion technique to remove portions of grains which have suffered Pb-loss (Mattinson 2005). Chemically abraded zircons were washed several times in ultra-pure water, in warm $3 \mathrm{~N} \mathrm{HCl}$ for several hours on a hot-plate, rinsed again in ultra-pure water and $8 \mathrm{~N} \mathrm{HNO}_{3}$ and split into single grain fractions ready for dissolution. A mixed ${ }^{205} \mathrm{~Pb}-{ }^{235} \mathrm{U}$ tracer was used to spike all fractions. Dissolved, spike-equilibrated samples were not subjected to ion-exchange procedures but were converted to chloride and loaded on to degassed rhenium filaments in silica gel following a procedure modified after Mundil et al. (2004). Isotope data (Table 2) were collected using a Thermo Electron Triton equipped with a new generation of MassCom Secondary Electron Multiplier (Noble et al. 2006). A minimum of 100 ratios were collected for $\mathrm{Pb}$ and 60 for $\mathrm{U}$. $\mathrm{Pb}$ ratios were scrutinized for any evidence of organic interferences which were determined to be negligible. Errors were calculated using numerical error propagation (Ludwig 1998). Isotope ratios were plotted using Isoplot version 3 (Ludwig 2003), and error ellipses and ages presented reflect $2 \sigma$ uncertainty. Total procedural blanks were $0.2 \mathrm{pg}$ for $\mathrm{Pb}$ and $0.05 \mathrm{pg}$ for 
U. Samples were blank corrected for $0.2 \mathrm{pg}$ of $\mathrm{Pb}$, any residual common $\mathrm{Pb}$ was corrected using a Stacey-Kramers common lead composition (Stacey \& Kramers 1975).

\subsubsection{New U-Pb age}

Despite strong chemical abrasion, seven out of nine zircon fractions are discordant as a result of Pb-loss. All data define a discordia with an upper intercept age of $399.8 \pm 1.1 \mathrm{Ma}$ (mean square weighted deviation (MSWD) 0.31; Fig. 11). Two of the zircon fractions (Z4 and Z11) are concordant and yield a concordia age of $399.3 \pm 0.7 \mathrm{Ma}$ (concordance and equivalence: MSWD 0.57, probability 0.63). Although within error of the upper-intercept age calculation, the concordia age is more precise, so we regard this as the best estimate of the age of emplacement of the Weardale Pluton.

The new $\mathrm{U}-\mathrm{Pb}$ zircon age is the first unequivocal emplacement age, and this confirms that the Weardale Pluton belongs to the suite of similar high heat-flow granites emplaced across northern England during the later stages of the Acadian deformation event (Millward 2002; Soper \& Woodcock 2003). In a broader context, this high-precision age permits a more detailed correlation of early to mid-Devonian magmatism across the orogen. Such highprecision dating is a prerequisite for understanding magmatic-mineralizing systems. In the case of the Weardale Pluton the Re-Os molybdenite age of $398 \pm 1.6$ Ma (Selby et al. 2008) overlaps within error the new U-Pb zircon concordia age.

\subsection{Sub-Carboniferous exposure of the granites}

Lower Palaeozoic rocks exposed within the Pennine Fault Zone are intruded by several felsic minor intrusions, the largest of which is the Dufton Microgranite (Harker \& Marr 1891; Shotton 1935; Hudson 1937). This red microgranite, exposed on the west side of Dufton Pike [NY 6930 2681], is characterized by abundant phenocrysts of quartz, feldspar and euhedral crystals of muscovite up to $25 \mathrm{~mm}$ across (Burgess \& Holliday 1979). Although no age determinations are available for any of these minor intrusions, they are regarded as being genetically and temporally associated with the granite mass.

The Rookhope and Eastgate boreholes, both sited on the upper surface of the Weardale Pluton, demonstrated that granite was un-roofed and exposed to erosion prior to deposition of the lowest Carboniferous sediments. Rapid uplift in the region following the Acadian deformation and magmatism would have led to extensive erosion, producing appreciable 
accumulations of locally derived, coarse debris, including those which crop out today within the Cross Fell Inlier as the Middle to Upper Devonian 'Polygenetic Conglomerate' (Shotton 1935; Arthurton \& Wadge 1981), probably equivalent to the Mell Fell Conglomerate Formation of the Lake District; Mississippian conglomerates along the Pennine escarpment and in the Cronkley Inlier of Upper Teesdale belong to the Marsett Sandstone Formation (Ravenstonedale Group; Waters et al. 2007).

The main clast types within these conglomerates are mudstone and greywacke sandstone typical of Skiddaw Group rocks, together with Borrowdale Volcanic Group lithologies (Burgess \& Holliday 1979; Arthurton \& Wadge 1981). Vein quartz pebbles are locally common together with, in the Polygenetic Conglomerate at Acorn Sike, near Ousby Townhead [NY 64553408 ], a few pebbles of feldspar-porphyry similar to that known in a minor intrusion at a nearby outcrop today in the Skiddaw Group rocks of the Cross Fell Inlier.

The nearest exposures of conglomerate to the subcrop of the Weardale Granite Pluton are those at Cronkley Fell, on the southern margins of the Teesdale Inlier, and Falcon Clints at the western extremity of the inlier. Harry (1950) concluded that the assemblage here of rhyolitic and andesitic pebbles of Borrowdale Volcanic Group origin, accompanied by mudstone from the Skiddaw Group, provided evidence of local derivation. However, despite their proximity to likely contemporaneous exposures of the Weardale Pluton, no fragments of this rock have been found in these or any of the other conglomeratic deposits that lie beneath or within the local Carboniferous succession. If, as seems probable, granite clasts were formed during early Carboniferous erosion of the pluton, the configuration of the local drainage pattern apparently did not distribute them to the conglomeratic deposits exposed today.

A few boulders of weathered granite have been recorded within the Polygenetic Conglomerate at Acorn Sike [NY 6455 3408] (Arthurton \& Wadge 1981). The granite is composed of K-feldspar phenocrysts set in an anhedral granular groundmass of quartz, biotite and plagioclase (BGS thin section no. E36178). The absence of muscovite suggests that this rock is distinct from the Weardale Pluton and, in our opinion, from the Lake District granites, though some resemblance to the finest grained facies of such Lake District granites as those of Shap, Skiddaw and Eskdale was claimed by Arthurton \& Wadge (1981). Considerations of likely Devonian palaeogeography make derivation from a source within the area of the Lake 
District unlikely. Local derivation, as proposed by Arthurton \& Wadge, seems more likely. If so, and in view of the proximity of the well-defined Tynehead and Scordale plutons, either or both of which could have been partially unroofed during Devonian times, it is possible that these fragments of hitherto unidentified biotite-granite may be derived from one of these bodies.

\section{RELATIONSHIP BETWEEN THE PLUTONS AND MINERALIZATION}

The likely genetic significance of the zoning of mineralization was of prime importance in predicting the presence of the concealed granite mass, as confirmed in the Rookhope Borehole (Dunham et al. 1961, 1965). Whereas subsequent studies have linked the orefield's mineralization with particular features of the batholith, most models of orefield genesis regard the batholith as a single body responsible for the genesis of these deposits. However, in this section we recognize patterns and styles of mineralization that appear to be associated with individual plutons that comprise the North Pennine batholith.

\subsection{Mineralization associated with the Weardale Granite Pluton}

The rocks exposed at surface in this area, which includes the former mining districts of East Allendale, the Derwent Valley, Rookhope, Weardale and Teesdale, lie mostly above the level of the Great Limestone (Serpukhovian): lower (Visean) strata are exposed in the main valleys and were penetrated in some of the deeper mine workings. Most of the veins, which carried many of the orefield's largest and most productive deposits of both ore and gangue minerals, lie above the roof of the pluton. Also, most of the known veins lie within the zone of fluoritedominated mineralization. Despite comparable levels of exposure, peripheral bariumdominated assemblages, although present locally, are much less numerous than in the periphery of either the Tynehead or Scordale plutons.

Two principal vein directions may readily be distinguished above the Weardale Pluton. Most numerous are the roughly SW-NE 'lead veins' and the fewer, but generally longer, WNWtrending 'Quarter-point' suite of veins (Dunham 1990). The latter groups of veins, from north to south, the White Vein, Rookhope Red Vein and Sedling-Slitt Vein systems (WV, RV and SV in Fig. 1), are evenly spaced parallel structures above the roof region of the pluton. As the orefield's major sources of fluorspar, these veins have been explored and worked to greater depths than most of the SW-NE veins. 
The 'Quarter-point' structures include large oreshoots which extend downward beyond mined depths, for example at Burtee Pasture [NY 860 413], Groverake [NY 896 442], Slitt [NY 906 392] and Cambokeels [NY 937 383]. In these, a progressive downwards passage into zones dominated by abundant quartz and iron sulphides, including pyrrhotite, together with the localized incoming of copper, bismuth, rare-earth-element and rare tin mineralization, and fluid inclusions indicative of increasing mineralization temperatures with depth, have been cited as evidence of the presence of emanative centres up which mineralizing fluids rose and spread laterally (Ixer 1986; Dunham 1990; Ixer et al. 1996). Vein intersections recorded in the Weardale Granite in the Rookhope Borehole and interpreted as the downward extension of Boltsburn Vein, were found to carry similar quartz-pyrrhotite-rich assemblages, suggesting that the SW-NE 'lead veins' may also pass down into zones dominated by quartz and iron sulphides (Dunham et al. 1965).

Significant concentrations of intensely mineralized veins in Teesdale lie above the steep southern flank of the pluton, for example at the Pike Law Mines, and may mark a further emanative centre (Bridges \& Young 2007). No comparable concentrations of mineralization are known above the steep northern flank.

\subsection{Mineralization associated with the Tynehead Pluton}

Though smaller than the Weardale Pluton, this body is also associated with significant mineralization within the overlying Carboniferous rocks which are here predominantly of Visean age, though with some small outcrops of Great Limestone and overlying Serpukhovian strata.

Like the veins above the Weardale Pluton, those above the roof of the Tynehead Pluton lie mainly within the fluorite zone of mineralization. The longest and most prominent group of these veins is that of the Great Sulphur Vein, and its associated branches, which lie directly above the axis of the pluton (GSV in Fig. 1). From detailed descriptions by Thompson (1933) and Dunham (1990), it is clear that this major vein system is distinguished by its great widths of mineralization (over $360 \mathrm{~m}$ at one point near Tynehead) and its filling, predominantly of quartz at higher levels, passing down into a lower zone rich in iron sulphides. Its general WNW-ESE orientation and its mineral content invite close comparison with the lower levels of the 'Quarter-point' veins above the Weardale Pluton, particularly the lowest explored levels of the Slitt Vein at Cambokeels Mine. The Great Sulphur Vein may represent a major 
'Quarter-point' vein from which the upper, perhaps fluorite- and galena-bearing zones have been removed by erosion.

A number of mainly small veins above the roof of the Tynehead Pluton carry abundant copper mineralization, apparently unaccompanied by significant lead and/or zinc minerals. These appear to be unique within the orefield in having been worked, albeit on a small scale, for copper ores. Small concentrations of copper mineralization at depth, associated with the Weardale Pluton, though never of workable grade, have been taken as indicative of proximity to local emanative centres of mineralization. These copper-rich occurrences above the Tynehead body, together with a number of small concentrations of cobalt, nickel and rareearth-element mineralisation may mark similar emanative centres associated with this pluton.

Deposits characterized by abundant barium minerals are more numerous within the periphery of the Tynehead Pluton than the Weardale body. These include the baryte deposits of the Hartside mines [NY 644 430] and the numerous veins of the Nent valley in which barium carbonate minerals are prominent. The latter area is notable for the extensive replacement of originally deposited baryte by the barium carbonate minerals witherite, barytocalcite and alstonite (Hancox 1934; Young 1985).

\subsection{Mineralization associated with the Scordale Pluton}

Despite similarities in surface geology and degree of exposure above the Tynehead and Scordale plutons, the latter area exhibits a markedly smaller number of veins. With the exception of the small, but richly mineralized, group of deposits at the head of Scordale [NY 755 226], above the southern crest of the pluton, very few veins are known to lie above its roof. The only other formerly economic concentrations of mineralization spatially associated with this body are those of the Dufton [NY 715 277] and Silverband [NY 703 317] mines, which lie above its western and northern flanks respectively.

The veins visible above the Scordale Pluton lie mainly within the outer, barium, zone of the orefield (Dunham 1948). Fluorite is confined to the head of Scordale. Whereas it is possible that more extensive fluorite mineralization remains concealed, it is important to note that fluorite and barium minerals occur together in the Scordale deposits in almost equal abundance, reminiscent of some of the Askrigg Block deposits to the south (Dunham \& Wilson 1985), rather than elsewhere in the Alston Block, where the occurrence of fluorite and baryte is almost mutually exclusive. 


\subsection{Mineralization associated with the Cornsay Pluton}

At the surface, Pennine Coal Measures Group rocks of the Durham Coalfield lie above this pluton. Although such rocks are generally unfavourable to hosting mineral veins, two principal vein systems, the Great Spar Dyke-South Moor Vein and the Deerness Valley Fault System, which lie above the northern and southern flanks respectively of the pluton, carried substantial workable bodies of baryte and witherite, with only very modest and uneconomic sulphide values. The composition of these veins in depth is unknown.

\subsection{Mineralization associated with the Rowlands Gill Pluton}

Although intensively worked for coal over several centuries and at similar levels of exposure to those above the Cornsay Pluton, known mineralization in the Westphalian rocks above the Rowlands Gill Pluton is limited to a single witherite-calcite-bearing vein at Tanfield Moor Colliery [NZ 1699 5438].

\subsection{Areas of zinc-rich mineralization}

In the Nent valley and at the head of Weardale, one of the orefield's densest concentrations of mineralization lies above the northern flank of the Tynehead Pluton and extends across a broad embayment between this body and the Weardale Pluton (Fig. 5). Many of these vein and replacement orebodies, which are clearly associated with major NW-SE 'Cross-veins', are characterized by high concentrations of sphalerite accompanied by iron and lead minerals, but typically without either fluorite or barium gangue minerals (Dunham 1990). Their close relationship with the 'Cross-veins' suggests that these fractures here provided open channels for mineralizing fluids, perhaps during the early part of the mineralizing episode. Elsewhere in the orefield, these fractures are typically non-mineralized suggesting that for substantial periods, perhaps later in the genesis of the deposits, they were tightly closed and unavailable for the passage of ore-bearing fluids.

Similar zinc and iron-rich mineralization to that of the Nent valley, but without associated lead minerals, occurs at Ettersgill [NY 805 336] and Wynch Bridge [NY 907 275] in Teesdale, above the southern flank of the Weardale Pluton. These deposits are associated with E-W or NE-SW fractures, not with 'Cross-veins'. 


\subsection{Mineralization along the Alston Block margins}

The small group of veins centred around Haydon Bridge on the north side of the Tyne valley, from which lead and zinc ores and large tonnages of witherite have been raised, has traditionally been regarded as an outlying portion of the barium zone of the orefield (Dunham 1990). Hosted in Visean and Serpukhovian sedimentary (and locally Great Whin Sill) wallrocks, these veins, like their mineralogically related counterparts in the main orefield approximately $10 \mathrm{~km}$ to the south, were deposited from fluids derived from the SolwayNorthumberland Trough, mobilized by the thermal effects of the North Pennine batholith (Dunham 1990; Crowley et al. 1997). However, as they occupy antithetic faults with throws of up to $90 \mathrm{~m}$ in the hangingwall of the Stublick Fault Zone, they may be more appropriately viewed as part of a wider belt of mineralization related to the southern margin of the SolwayNorthumberland Trough (Cooper et al. 1991; Young et al. 1992).

A small group of veins hosted in similar rocks within the Lunedale Fault System, occupy an analogous position to those of the Haydon Bridge area, on the southern margin of the Alston Block. In this case the mineralizing fluids are likely to have been drawn from the Stainmore Basin to the south.

\section{DISCUSSION}

We interpret our three-dimensional (3D) gravity model to indicate five separate intrusive foci with the contiguous plutons merging at depth to form the larger batholith. Seismic evidence supports the connection at depth between the Weardale and Cornsay bodies inferred from gravity modelling (Figs 5, 7, 8 and 9). There is little evidence to suggest a density contrast between the adjacent plutons. The flanks of the plutons are steep, especially given the fact that 3D gravity inversion methods tend to underestimate their dips (compare, for example, with the profile models of Kimbell et al. 1989; Kimbell et al. 2006). The modelled tops of all five of the plutons lie at or close to the top surface of the Lower Palaeozoic basement in both the alternative gravity models presented in this paper. This is to some extent a consequence of the modelling inputs and assumptions, but these were constrained by the requirement to honour the provings in the Rookhope and Eastgate boreholes. Such an interpretation is consistent with the seismic evidence from the eastern side of the batholith and it also has some support from magnetic imaging, although the latter is complicated by signatures from the overlying Great Whin Sill. 
The gravity model shows a buried granite ridge extending west-north-west from the northern part of the Weardale Pluton. This lies in an area where there is no seismic control, as the commercial seismic reflection lines in the Northumberland Basin terminate farther north, so an alternative explanation is that there is a thickening of the Carboniferous sedimentary sequence along this axis. Whichever explanation applies, the northern edge of this feature aligns with that of the Weardale Pluton, a trend which parallels an alignment between the southern edge of the Weardale Pluton and the northern edge of the Scordale Pluton (Fig. 5).

It is constructive to compare our model with that of the neighbouring Lake District batholith about which much more is known. Covering about $1500 \mathrm{~km}^{2}$, the Lake District batholith is of similar size to that beneath the north Pennines (Fig. 12). Exposed plutons include Eskdale, Ennerdale, Shap and Skiddaw, but gravity modelling has enabled recognition of many other discrete, concealed masses (Lee 1986, 1989). Precise U-Pb zircon ages of the exposed plutons are clustered, giving late Ordovician, volcanic-related ages (450-452 Ma) from those that form the core of the batholith, and early Devonian ages (c. $400 \mathrm{Ma}$ ) from those located around its margin (Hughes et al. 1996; Millward 2002; Millward \& Evans 2003; Selby et al. 2008). The Ordovician components (e.g. Eskdale and Ennerdale) have been inferred to comprise tabular, laccolithic intrusions interdigitated with country rock such that their western margins exhibit a 'cedar tree' form (Evans et al. 1994). By contrast, the Devonian Shap and Skiddaw plutons are steep-sided conical bodies (Lee 1989), as is the Devonian Cheviot Granite in north Northumberland (Lee 1982) and major Devonian plutons in southern Scotland (Kimbell et al. 2006 and references therein). An Ordovician age is inferred for the spatially separate Wensleydale Granite beneath the Askrigg Block, although reliable dating is required to confirm this (Pharaoh et al. 1997; Kirkby et al. 2000). Gravity modelling suggests that this body has a smaller depth extent than the Lake District and Northern Pennine intrusions (Fig. 12; Kimbell et al., 2006).

The new $\mathrm{U}-\mathrm{Pb}$ data presented in this paper conclusively demonstrate the Devonian age of the Weardale Pluton $(399.3 \pm 0.7 \mathrm{Ma})$. The similarly steep-sided and deep-seated forms of the four other plutons strongly suggest that they are also of Devonian age. The granite mass contains only modest internal seismic contrasts, limited to dipping features interpreted to be fracture zones and some diffuse flatter-lying reflectivity. Confirmation that this character is real, and not just related to data quality, is provided by the clear imaging of lower crustal reflectivity beneath the granite (see also Ward 1992). By contrast, seismic reflection surveys over the Ordovician plutons of the Lake District batholith reveal much stronger reflectivity 
contrasts, which are interpreted as the signatures of interleaved lenses of granite and country rock (Fig. 13; Evans et al. 1994; Chadwick \& Evans 2005). The contrasting pluton shapes could reflect different tectonic environments: the subduction-related and sub-volcanic (in the case of the Lake District) Ordovician plutons were intruded in a broadly extensional environment whereas the Devonian plutons were emplaced in a transpressional environment (Soper et al. 1987; Soper \& Woodcock 2003).

These observations have a bearing on current debate about pluton shapes and emplacement mechanisms. The view that has gained the majority support is that most plutons are sheeted, with aspect ratios that can be predicted using power-law expressions (e.g. McCaffrey \& Petford 1997; Cruden 1998; Petford \& Clemmens 2000; Cruden \& McCaffrey 2001; Taylor 2007). The evidence from northern England is that only the Ordovician plutons appear to comply with this prediction, and that the Devonian plutons are sub-circular bodies with depth extents that are of a similar order to their horizontal dimensions, and significantly greater than predicted by the published power-law relationships. A further category of funnel-shaped plutons has been identified (e.g. Vignoresse et al. 1999; Cruden \& McCaffrey 2001), but this does not fit the Devonian plutons of northern England. Gravity modelling indicates a steep outward dip for the flanks of these plutons rather than the shallow inward dip of the funnel model, and this is corroborated by comparison of the width at outcrop of the exposed examples at Shap, Skiddaw and Cheviot with the width required at depth from their gravity signatures (Lee 1982, 1989). There is indirect support for a conical shape for the plutons that make up the North Pennine batholith from the magnetic anomalies that flank these bodies (Fig. 10; Kimbell et al. 2006). For example, the position and wavelength of the Blanchland anomaly, on the northern flank of the Weardale Pluton, is compatible with a source extending to the basement surface on the flank of an outward dipping pluton margin. If the pluton was funnel-shaped the anomaly would be predicted to lie either further to the north or at greater depth.

There is a clear contrast between the east-north-east trend of the belt of plutons that comprise the Early Devonian components of the Lake District and North Pennine batholiths, and the west-north-west trend of the Ordovician plutons in the Lake District and the Wensleydale Granite (Fig. 12). Both trends may have early (Neoproterozoic?) antecedents (Kimbell \& Quirk 1999), and are also reflected by structures that were active during the Ordovician (the west-north-west trend associated with closure of the Tornquist Ocean between Avalonia and Baltica and the east-north-east trend with closure of Iapetus). However, the dominant 
influence on Devonian pluton emplacement, and thus on the form of the North Pennine batholith, appears to be east-north-east trending transpressional deformation in the footwall to the north-dipping Iapetus Suture. Such transpression could have provided mechanisms both for triggering the generation of magma and for controlling its emplacement (Leake 1990; Hutton \& Reavy 1992). Given that the shear sense was sinistral on these structures (Soper \& Hutton 1984), the disposition of the plutons is compatible with their development along tensional fracture systems bridging between major shear zones on the north and south side of the Alston Block. To the north, a concealed Acadian thrust zone along strike from the Causey Pike Thrust has been interpreted by Chadwick \& Holliday (1991) from seismic reflection data. To the south lies the extrapolation of the Southern Borrowdales Lineament, a further major Acadian structure. Under such a regime, extension could have provided sites for granite intrusion along structures parallel to the maximum horizontal stress direction (slightly east of north). The Tynehead and Scordale plutons may have developed along one such zone, Weardale along a second and Cornsay/Rowlands Gill along a third.

The gravity modelling is not particularly sensitive to the geometry assumed for the bases of the plutons (e.g. whether they are flat or irregular), but the fact that a satisfactory model can be constructed on the basis that all the components of the batholith extend to about the same depth may be instructive. A possible explanation for this is that the depth-extent of the plutons was controlled by the rheology of the host rocks at the time of emplacement rather than individual pluton volumes. The observed change in crustal reflectivity at a depth of about $12 \mathrm{~km}$ provides a possible indicator of the base of the granite. However, a model constructed with this constraint predicts a top granite surface that fits the seismic observations somewhat less well than one with a shallower base (Figs 8, 9), although a closer match would be possible if it was assumed that the density contrast increased with depth rather than being uniform. A further possible indication of the base of the granite is provided by an electrical conductivity increase detected by a magnetotelluric survey (Simpson \& Warner 1998) at a depth of about $10 \mathrm{~km}$, unless this is related to present-day brittle-ductile transition rather than a lithological change.

There is a correlation between a zone of demagnetized crust, as indicated by a longwavelength magnetic low (Fig. 10b), and the North Pennine batholith. Although this can be explained in part by magnetic contrasts between the batholith and the surrounding rocks, (most importantly the crystalline basement), the source of the low appears to extend to greater depth $(16-20 \mathrm{~km})$ than is required by gravity modelling of the batholith (Kimbell et al. 
2006; Kimbell \& Quirk 1999). The depth of demagnetization is, admittedly, not well constrained as it is dependent on assumptions about magnetization contrasts between deeply buried rocks, but the implication is either that the granite extends to greater depth than indicated by the gravity modelling, or that the magnetic properties of the underlying crust are modified by some other mechanism. A deeper extension of the intrusive body appears to be precluded by the seismic and magnetotelluric evidence although it is possible that the magnetic properties of the region beneath it were modified by secondary processes related to the intrusive episode.

A further possibility is that a contribution to the magnetic low is due to changes to magnetic minerals associated with hydrothermal or igneous activity post-dating emplacement of the batholith. The most likely process is alteration of pre-existing magnetite to non-magnetic phases, although other possibilities are the deposition of reversely magnetized mineralization, with pyrrhotite as the most likely candidate on the basis of the orefield evidence, or emplacement of a reversely magnetized intrusion beneath the granite. Cann \& Banks (2001) considered that the main (late Permian) mineralizing episode in the region resulted from deep hydrothermal circulation through a network of cracks which propagated downwards into the basement because of thermal contraction of the host rock in response to cooling by the circulating fluids (Russell 1978; Strens et al. 1987). There may well have been other episodes of hydrothermal circulation, given the evidence for very high pre-Whin Sill temperatures indicated by petrographic and vitrinite reflectance studies (Creaney 1980). The key factor distinguishing the non-mineralizing episode(s) from the mineralizing one may have been the hypersaline (Zechstein) nature of the fluids involved in the latter (Cann \& Banks 2001). What is uncertain is whether the hydrothermal systems could have extended deep enough and modified a sufficient proportion of the crust to have a detectable magnetic effect. Hydrofracturing would not be expected to extend below the brittle-ductile transition (300$450^{\circ} \mathrm{C}$ ), and Russell \& Hall (1988) argued that other processes (in particular pressure solution) will limit circulation to shallower depths. The temperatures of the mineralizing fluids at their maximum depth in the North Pennine hydrothermal system may not have been much larger than those estimated from fluid inclusion studies on near-surface veins (200$250^{\circ} \mathrm{C}$ ) if the return flow paths were relatively direct and involved only limited heat loss (Cann \& Banks 2001; Russell \& Hall 1988). On this basis Cann \& Banks (2001) estimated that the hydrothermal circulation extended to depths of up to $10 \mathrm{~km}$, which is less than that suggested by magnetic modelling. To link the basement demagnetization to hydrothermal 
circulation it would be necessary to demonstrate that such circulation depressed mid-crustal geotherms sufficiently to allow the 'cracking front' to extend into the mid-crust. The additional requirements are that the alteration was pervasive (i.e. not just along relatively widely spaced fractures), and that permeability was maintained for long enough for extensive alteration of magnetite (or deposition of reversely magnetized pyrrhotite) to occur.

The distribution and pattern of vein mineralization in relation to the form of the North Pennine batholith invites consideration of the role of individual plutons in the emplacement of the mineral deposits. The Weardale and Tynehead plutons clearly acted as major foci, channelling mineralizing fluids through the granites and into the Carboniferous rocks above their roofs and flanks. A feature of both plutons is the presence of major, Quarter Point structures: the Great Sulphur Vein system above the Tynehead Pluton, and the White Vein, Rookhope Red Vein and Slitt Vein systems of the Weardale Pluton. Concentrations of comparatively high temperature mineral assemblages at Tynehead, Rookhope and Pike Law may be evidence of emanative centres of mineralizing fluids close to high points on the Tynehead and Weardale plutons. Substantial concentrations of mineralization on the flanks of these plutons may reflect channelling of mineralizing fluids into receptive wall rocks in these regions.

It is noteworthy that mineralization associated with the Scordale Pluton is concentrated principally along the flanks of this body, with only minor deposits known above its roof region, despite good surface exposure. This distribution is consistent with fluids being channelled up the flanks of the pluton from the basinal areas to the south and west, perhaps without being circulated through the granite. The presence of significant mineralization in unfavourable (Pennsylvanian) wall rocks associated with the northern and southern flanks of the Cornsay Pluton suggests convective flow of mineralizing fluids related to that mass, though perhaps without passage through the pluton. The available evidence suggests that very much less mineralization may be associated with the Rowlands Gill Pluton.

The model of Cann and Banks (2001) involves the focussing of convective upflow above the region where subsurface temperatures were highest as a result of radiogenic heat production in the granite mass. Water transported upward in this 'chimney' would be replaced by lateral inflow from neighbouring, cooler country rock. In this context the term chimney is simply used to reflect the focus of a convective upwelling and does not imply any enhancement in permeability. The relationship between pluton geometry and mineralization described in the 
present paper suggests that such a chimney (or chimneys) may have been centred in the area occupied by the Weardale and Tynehead plutons. The fact that this appears to coincide with the region of strongest apparent demagnetization (Fig. 5b) provides some support for hypotheses that relate these phenomena to a common cause. If the granite and country rock have undergone the same degree of thermal cracking, and have similar permeabilities, the hydrothermal circulation could simply have been driven by thermal contrasts. In reality there may be permeability contrasts that modify the circulation. In particular, upflow may be directed along the flanks of a pluton rather than its centre if it is significantly less permeable than surrounding rocks. This provides a possible explanation for the concentration of mineralization on the flanks of the Scordale and Cornsay plutons. Such upflow would be short-lived, because of slow (conductive) heat transfer within the pluton leading to the chilling of its flanks, but might be extended if the crack network propagated laterally into it.

In addition to the associated mineralization, the North Pennine batholith has attracted interest for its geothermal potential, with the most recent investigations focusing on the possibility of 'mining' hot water from hydrogeologically-active fracture systems (Manning et al. 2007). Our results suggest that it may be possible to detect such fractures by seismic surveys, but only where near-surface conditions are favourable. Such exploration would be aided by the fact that the fracture zones will be most reflective where they contain the greatest volume of water. In addition, it would be possible to map fracture zones that are likely to have affected the granite by means of detailed aeromagnetic surveys targeting the influence of such zones on the overlying Great Whin Sill. The evidence from previous low resolution magnetic surveys (Fig. 10c) and limited high-resolution coverage (Cornwell \& Evans 1986) is that such surveys would be a powerful tool for structural mapping.

\section{Acknowledgements}

We gratefully acknowledge the helpful comments from Joe Cann, Martin Bott and an anonymous reviewer on previous versions of this paper. G.S.K. and D.M. publish with the permission of the Executive Director of the British Geological Survey (NERC). 


\section{References}

Arthurton, R. S. \& WAdGe, A. J. 1981. Geology of the country around Penrith. Memoir of the Geological Survey of Great Britain, England and Wales, Sheet 24.

Blakely, R. J. 1995. Potential theory in gravity and magnetic applications. Cambridge University Press, Cambridge.

Botт, M. H. P. 1967. Geophysical investigations of the northern Pennine basement rocks. Proceedings of the Yorkshire Geological Society, 36, 139-168.

BotT, M. H. P. 1974. The geological interpretation of a gravity survey of the English Lake District and the Vale of Eden. Journal of the Geological Society, London, 130, 309331.

Botт, M. H. P. 1978. Deep structure. 25-40 in The Geology of the Lake District. Moseley, F. (editor). Yorkshire Geological Society, Occasional Publication, 3.

Bott, M. H. P \& Masson-Smith, D. 1953. Gravity measurements over the northern Pennines. Geological Magazine, 90, 127-130.

BotT, M. H. P \& MASSON-SMITH, D. 1957a. The geological interpretation of a gravity survey of the Alston Block and the Durham Coalfield. Journal of the Geological Society of London, 113, 93-117.

BotT, M. H. P \& MASSON-SMiTh, D. 1957b. Interpretation of a vertical field magnetic survey in north-east England. Journal of the Geological Society of London, 113, 119-136.

Bott, M. H. P., Johnson, G. A. L., MAnsfield, J. \& WheILDON, J. 1972. Terrestrial heat flow in north-east England. Geophysical Journal of the Royal Astronomical Society, 27, 277-288.

Bott, M. H. P., Swinburn, P. M. \& LonG, R. E. 1984. Deep structure and origin of the Northumberland and Stainmore troughs. Proceedings of the Yorkshire Geological Society, 44, 479-495.

Bouch, J. E., Naden, J., Shepherd, T. J., McKervey, J. A., Young, B., Benham, A. J. \& SlOANE, H. J. 2006. Direct evidence of fluid mixing in the formation of stratabound $\mathrm{Pb}-\mathrm{Zn}-\mathrm{Ba}-\mathrm{F}$ mineralisation in the Alston Block, North Pennine Orefield (England). Mineralium Deposita, 41, 821-835. 
Bridges, T. F. \& Young, B. 2007. The geology and mineralogy of Pike Law mines, Newbiggin, Teesdale, Co. Durham. Journal of the Russell Society, 10, 18-26.

Burgess, I. C. \& Holliday, D. W. 1979. Geology of the country around Brough-underStainmore. Memoir of the Geological Survey of Great Britain, England and Wales, Sheet 31 .

CANN, J. R. \& BANKS, D. A. 2001. Constraints on the genesis of the mineralization of the Alston Block, Northern Pennine Orefield, northern England. Proceedings of the Yorkshire Geological Society, 53, 187-196.

Chadwick, R. A. \& Holliday, D. W. 1991. Deep crustal structure and Carboniferous basin development within the Iapetus convergence zone, northern England. Journal of the Geological Society, London, 148, 41-53.

Chadwick, R. A., \& Evans, D. J. 2005. A seismic atlas of southern Britain - images of subsurface structure. British Geological Survey, Occasional Publication, 7.

Chadwick, R. A., Holliday, D. W., Holloway, S. \& Hulbert, A. G. 1995. The structure and evolution of the Northumberland-Solway Basin and adjacent areas. Subsurface memoir of the British Geological Survey.

Cooper, D. C., Cameron, D. G., Young, B., Chacksfield, B. C. \& Cornwell, J. D. 1991. Mineral exploration in the Cockermouth area, Cumbria. Part 1: Regional surveys. British Geological Survey Technical Report WF/91/4.

Cornwell, J. D. \& Evans A. D. 1986. Magnetic surveys and structures in the Whin Sill, northern England. In: Nesbitt, R. W. \& Nichol, I. Geology in the real world - the Kingsley Dunham volume. The Institution of Mining and Metallurgy, London, 65-74.

CREANEy, S. 1980. Petrographic texture and vitrinite reflectance variation on the Alston Block, north-east England. Proceedings of the Yorkshire Geological Society, 42, 553580.

Crowley, S.F., Bottrell, S.H., McCarthy, B., Ward, J. \& Young, B. 1997. $\delta^{34}$ S of Lower Carboniferous anhydrite, Cumbria and its implications for barite mineralization in the northern Pennines. Journal of the Geological Society of London, 154, 597-600.

CRUDEN, A. R. 1998. On the emplacement of tabular bodies. Journal of the Geological Society, London, 155, 853-862. 
Cruden, A. R. \& McCAffrey, K. J. W. 2001. Growth of plutons by floor subsidence: implications for rates of emplacement, intrusion spacing and melt extraction mechanisms. Physics and Chemistry of the Earth (A), 26, 303-315.

DABEK, Z. K. \& Williamson, J. P. 1999. Forward and inverse wavenumber formulae for the gravity and magnetic responses of layered models. British Geological Survey Technical Report, WK/99/03C.

Dodson M. H. \& Moorbath, S. 1961. Isotopic ages of the Weardale Granite. Nature, London, 90, 899.

DunHaM, K. C. 1934. Genesis of the North Pennine ore deposits. Quarterly Journal of the Geological Society, London, 90, 689-720.

Dunham, K. C. 1948. Geology of the Northern Pennine Orefield, 1 Tyne to Stainmore. Economic Memoir of the Geological Survey of Great Britain.

DunHAM, K. C. 1982. Ore genesis in the English Pennines: a fluoritic subtype. Proceedings of the International Conference on Mississippi Valley Type Lead-Zinc Deposits. Rolla. Missouri. 86-112.

DunhaM, K. C. 1990. Geology of the Northern Pennine Orefield; Volume 1 Tyne to Stainmore. Economic Memoir of the British Geological Survey, England and Wales, Sheets 19 and 25, and parts of 13, 24, 26, 31, 32. Second Edition.

Dunham, K. C., Bott, M. H. P., Johnson, G. A. L. \& Hodge, B. L. 1961. Granite beneath the Northern Pennines. Nature, London, 190, 899-900.

Dunham, K. C., Dunham, A. C., Hodge, B. L. \& Johnson, G. A. L. 1965. Granite beneath Viséan sediments with mineralisation at Rookhope, North Pennines. Quarterly Journal of the Geological Society, London, 121, 383-417.

DunhaM, K.C. \& WiLson, A.A. 1985. Geology of the Northern Pennine Orefield; Volume 2 Stainmore to Craven. Economic Memoir of the British Geological Survey, England and Wales, Sheets 40, 41, and 50 and parts of 31, 32, 51, 60 and 61.

England, P. C., Oxburgh, E.R., \& Richardson, S. W. 1980. Heat refraction and heat production in and around granite plutons in north-east England. Geophysical Journal of the Royal Astronomical Society, 62, 439-455. 
Evans, C. J., Kimbell, G. S. \& Rollin, K. E. 1988. Hot Dry Rock potential in urban areas. Investigation of the Geothermal Potential of the UK, British Geological Survey.

Evans, D. J., Rowley, W. J., Chadwick, R. A., Kimbell, G. S. \& Millward, D. 1994. Seismic reflection data and the internal structure of the Lake District batholith, Cumbria, northern England. Proceedings of the Yorkshire Geological Society, 50, 11-24.

Fitch F. J., \& MiLler, J. A. 1965. Age of the Weardale Granite. Nature, 208, 743-745.

Gebski, J. S., Wheildon, J. \& Thomas-BetTs, A. 1987. Investigations of the UK heat flow field (1984-1987). Investigation of the Geothermal Potential of the UK British Geological Survey.

Gillespie, M R., Stephenson, D. \& Millward, D. 2008. Proposals for classifying lithodemic units of intrusive rock. British Geological Survey Research Report RR/08/05.

HARKER, A. \& MARR, J. E. 1891. The Shap Granite and associated rocks. Quarterly Journal of the Geological Society, London, 47, 266-328.

HARRY, W. T. 1950. Basement Carboniferous in Upper Teesdale, N Yorks. Geological Magazine, 87, 297-299.

Holland, J. G. 1967. Rapid analysis of the Weardale Granite. Proceedings of the Yorkshire Geological Society, 36, 91-114.

Holland, J. G. 1980. The Weardale Granite. In The Geology of north east England. Robson, D. A. (Editor). Special Publication of the Natural History Society of Northumbria. The Hancock Museum, Newcastle-upon-Tyne. 61-62.

Holland, J. G. \& Lambert, R. St J. 1970. Weardale Granite. Transactions of the Natural History Society of Northumberland, Durham and Newcastle-upon-Tyne, 41, 103118.

Hudson, S. N. 1937. The volcanic rocks and minor intrusions of the Cross Fell Inlier, Cumberland and Westmorland. Quarterly Journal of the Geological Society, London, 93, 368-405.

Hughes, R. A., Evans, J. A., Noble, S. R. \& Rundle, C. C. 1996. U-Pb chronology of the Ennerdale and Eskdale intrusions supports sub-volcanic relationships with the 
Borrowdale Volcanic Group (Ordovician, English Lake District). Journal of the Geological Society, London, 153, 33-38.

Hutton, D. H. W. \& Reavy, R. J. 1992. Strike-slip tectonics and granite petrogenesis. Tectonics, 11, 960-967.

IXER, R. A. 1986. The ore mineralogy and paragenesis of the lead-zinc-fluorite-baryte orefields of the English Pennines and Mendip Hills. Pp. 179-211 in: CRAIG, J. R. (editor) Mineral Parageneses. Theophrastus, Athens.

Ixer, R. A., Young, B. \& Stanley, C. J. 1996. Bismuth-bearing assemblages from the Northern Pennine Orefield. Mineralogical Magazine, 60, 317-324.

Kimbell, G. S. \& Quirk, D. G. 1999. Crustal magnetic structure of the Irish Sea region: evidence for a major basement boundary beneath the Isle of Man. In In sight of the suture: the geology of the Isle of Man in its Iapetus Ocean context. Woodcock, N. H., Quirk, D. G., Fitches, W. R. and Barnes, R. P. (editors). Special Publication of the Geological Society, London, 160, 227-238.

Kimbell, G. S., Chadwick, R. A., Holliday, D. W. \& Werngren, O. C. 1989. The structure and evolution of the Northumberland Trough from new seismic reflection data and its bearing on modes of continental extension. Quarterly Journal of the Geological Society, London, 146, 775-787.

Kimbell, G. S., Carruthers, R. M., Walker, A. S. D., \& Williamson, J. P. 2006. Regional Geophysics of Southern Scotland and Northern England. Version 1.0 on CD-ROM. British Geological Survey, Keyworth, Nottingham.

Kirby, G. A., Baily, H. A., Chadwick, R. A., Evans, D. J., Holliday, D. W., Holloway, S., Hulbert, A. G., Pharaoh, T. C., Smith, N. J. P., Aitkenhead, N. \& Birch, B. 2000. The structure and evolution of the Craven basin and adjacent areas. Subsurface Memoir of the British Geological Survey.

Klemperen, S. L. \& HobBS, R. W. 1991. The BIRPS Atlas. Deep seismic reflection profiles around the British Isles. (Cambridge: Cambridge University Press.)

LEAKE, B. E. 1990. Granite magmas: their sources, initiation and consequences of emplacement. Journal of the Geological Society, London, 147, 579-589.

LEE, M. K. 1982. Regional geophysics of the Cheviot area. Institute of Geological Sciences, Report ENPU82-2. 
LEE, M. K. 1984. The three-dimensional form of the Lake District granite batholith. Investigation of the geothermal potential of the UK, British Geological Survey.

LEE, M. K. 1986. A new gravity survey of the Lake District and three-dimensional model of the granite batholith. Journal of the Geological Society, London, 143, 425-435.

LEE, M. K. 1989. Upper crustal structure of the Lake District from modelling and image processing of potential field data. British Geological Survey Technical Report, WK/89/1.

Lee, M. K., Brown, G. C., WebB, P. C., Wheildon, J. \& Rollin, K. E. 1987. Heat flow, heat production and thermo-tectonic setting in mainland UK. Journal of the Geological Society, London, 144, 35-42.

Liss, D., Owens, W. H. \& Hutton, D. H. W. 2004. New palaeomagnetic results from the Whin Sill complex: evidence for a multiple intrusion event and revised virtual geomagnetic poles for the late Carboniferous of the British Isles. Journal of the Geological Society, London, 161, 927-938.

LuDWIG, K. R. 1998. On the treatment of concordant uranium-lead ages. Geochimica et Cosmochimica Acta, 62, 665-676.

LuDwIG, K. R. 2003. Isoplot/Ex version 3.0. A Geochronological toolkit for Microsoft Excel. Berkeley Geochronology Center Special Publication No.4, 70p.

Macdonald, R, Wilson, L, Thorpe, R S, \& Martin, A. The Cleveland Dyke - evidence from geochemistry, mineralogy, and physical modelling. Journal of Petrology, 29, $559-583$.

Manning, D. A. C., Younger, P. L., Smith, F. W., Jones, J. M., Dufton, D. J. \& Diskin, S. 2007. A deep geothermal exploration well at Eastgate, Weardale, UK: a novel exploration concept for low-enthalpy resources. Journal of the Geological Society, London, 164, 371-382.

MAtTinson, J. M., 2005. Zircon U-Pb chemical abrasion ("CA-TIMS") method: Combined annealing and multi-step partial dissolution analysis for improved precision and accuracy of zircon ages. Chemical Geology, 220, 47-66.

MCCAffrey, K. J. W. \& PetFord, N. 1997. Are granitic intrusions scale invariant? Journal of the Geological Society, London, 154, 1-4. 
Mills, D. A. C. \& Holliday, D. W. 1998. Geology of the district around Newcastle upon Tyne, Gateshead and Consett. Memoir of the Geological Survey of Great Britain, England and Wales, Sheet 20.

MiLlward, D. 2002. Early Palaeozoic magmatism in the English Lake District. Proceedings of the Yorkshire Geological Society, 54, 65-93.

Millward, D. \& Evans, J. A. 2003. U-Pb chronology and duration of upper Ordovician magmatism in the English Lake District. Journal of the Geological Society, London, 160, $773-781$.

Mundil, R., Ludwig, K. R., Metcalfe, I. \& Renne, P. R. 2004. Age and timing of the Permian mass extinctions: $\mathrm{U} / \mathrm{Pb}$ dating of closed-system zircons. Science, 305, 17601763.

Noble, S. R., Tucker, R. D. \& Pharoah, T. C. 1993. Lower Paleozoic and Precambrian igneous rocks from eastern England and their bearing on late Ordovician closure of the Tornquist sea: constraints from U-Pb and $\mathrm{Nd}$ isotopes. Geological Magazine, $130,835-846$.

Noble, S., Schweiters, J., Condon, D. J., Crowley, Q. G., QuaAs, N. \& Parrish, R. 2006. TIMS characterization of new generation of secondary electron multiplier. Eos Trans. AGU, 87(52), Fall Meeting Supplement, http://www.agu.org/meetings/fm06/?content=program\&show $=\mathrm{cd}$.

OldENBURG, D. W. 1974. The inversion and interpretation of gravity anomalies. Geophysics, 39, 526-536.

PARKER, R. L. 1972. The rapid calculation of potential anomalies. Geophysical Journal of the Royal Astronomical Society, 31, 447-455.

Petford, N. \& Clemmens, J. D. 2000. Granites are not diapiric! Geology Today. SeptemberOctober issue, $180-184$.

Pharaoh, T. C., Allsop, J. M., Holliday, D. W., Merriman, R. J., Kimbell, G.S., Rundle, C. C., Brewer, T. S., Noble, S. R. \& Evans, C. J. 1997. The Moorby Microgranite: a deformed high level intrusion of Ordovician age in the concealed Caledonian basement of Lincolnshire. Proceedings of the Yorkshire Geological Society, 51, 329342. 
Robinson, D. 1970. Metamorphic rocks. 119-121 in Geology of Durham County. Transactions of the Natural History Society of Northumberland, Durham and Newcastle upon Tyne, $\mathbf{4 1 .}$

RoLLIN, K. E. 1988. GM3D: forward and iterative 3-D gravity and magnetic modelling using vertical square prisms. British Geological Survey Technical Report, WK/88/17.

Russell, M. J. 1978. Downward-excavating hydrothermal cells and Irish-type ore deposits:importance of an underlying thick Caledonian prism.. Transactions of the Institution of Mining and Metallurgy (Section B: Applied Earth Science), 82, B168B171.

Russell, M. J. \& HALL, J. 1988. Mechanics of downward permeation of water in crystalline rock, with application to problems of geothermal energy extraction. Transactions of the Institution of Mining and Metallurgy (Section B: Applied Earth Science), 97, B51B56.

SelBy, D., CONLIFFE, J., CROWLEY, Q. G. \& FEELY, M. 2008. Geochronology (Re-Os and $\mathrm{U}-\mathrm{Pb}$ ) and fluid inclusion studies of molybdenite mineralisation associated with the Shap, Skiddaw and Weardale granites, UK. Applied Earth Science, 117, 11-28.

ShOtTON F. W. 1935. The stratigraphy and tectonics of the Cross Fell Inlier. Quarterly Journal of the Geological Society, London, 91, 639-700.

SiMPSON, F. \& WARNER, M. 1998. Coincident magnetotelluric, P-wave and S-wave images of the deep continental crust beneath the Weardale granite, NE England: seismic layering, low conductance and implications against the fluids paradigm. Geophysical Journal International, 133, 419-434.

Soper, N. J. \& HutTON, D. H. W. 1984. Late Caledonian sinistral displacements in Britain implications for a 3-plate collision model. Tectonics, 3, 781-794.

Soper, N. J. \& Woodcock, N. H. 2003. The lost Lower Old Red Sandstone of England and Wales: a record of post-Iapetan flexure or Early Devonian transtension? Geological Magazine, 140, 627-647.

Soper, N. J., WebB, B. C. \& Woodcock, N. H. 1987. Late Caledonian (Acadian) transpression in north-west England: timing, geometry and geotectonic significance. Proceedings of the Yorkshire Geological Society, 46, 175-192. 
Soper, N. J., England, R. W., Snyder, D. B. And Ryan, P. D. 1992a. The Iapetus suture zone in England, Scotland and eastern Ireland: a reconciliation of geological and deep seismic data. Journal of the Geological Society, London, 149, 697-700.

Snyder, D. \& HobBS, R. 1999. The BIRPS Atlas II. A Second Decade of Deep Seismic Reflection Profiling. The Geological Society, London (on CD-ROM).

StACEY, J. S. \& KRAMERS, J. D. 1975. Approximation of terrestrial lead isotope evolution by a two-stage model. Earth and Planetary Science Letters 26, 207-221.

Stone, P., Millward, D, Young, B., Merritt, J. W., Clarke, S. M., McCormac, M. \& LAWRENCE, D. J. D. 2010. British Regional Geology: Northern England. $5^{\text {th }}$ edition. (Keyworth, Nottingham: British Geological Survey.)

StRENS, M. R., CANN, D. L. \& CANN, J. R. 1987. A thermal balance model of the formation of sedimentary-exhalative lead-zinc deposits. Economic Geology, 82, 1192-1203.

TAYLOR, G. K. 2007. Pluton shapes in the Cornubian Batholith: new perspectives from gravity modelling. Journal of the Geological Society, London, 164, 525-528.

Thompson, L. M. 1933. The Great Sulphur Vein of Alston Moor. Proceedings of the University of Durham Philosophical Society, 9, 91-98.

Trotter, F. M. 1954. The genesis of the high rank coals. Proceedings of the Yorkshire Geological Society, 29, 267-303.

Vignoresse, J.-L., Tikoff, B., \& AmÉGlio, L. 1999. Modification of the regional stress field by magma intrusion and formation of tabular granitic plutons. Tectonophysics, $\mathbf{3 0 2}$, 203-224.

WARD, G., WARNER, M. \& BIRPS SYNDICATE. 1991. Lower crustal lithology from shear wave seismic reflection data. American Geophysical Union, Geodynamics Series, 22, 343-349.

Waters, C. N., Browne, M. A. E., DeAn, M. T. \& Powell, J. H. 2007. Lithostratigraphical framework for Carboniferous successions of Great Britain (Onshore). British Geological Survey, Research Report RR/07/01.

WoolacotT, D. 1923. A boring at Roddymoor Colliery, near Crook, Co. Durham. Geological Magazine, 60, 50-62. 
YounG, B. 1985. The distribution of barytocalcite and alstonite in the Northern Pennine Orefield. Proceedings of the Yorkshire Geological Society, 45, 199-206.

Young, B., Styles, M.T. \& BerRidge, N.G. 1985. Niccolite-magnetite mineralization from Upper Teesdale, North Pennines. Mineralogical Magazine, 49, 555-559.

Young, B., Millward, D. \& CoOPer, D. C. 1992. Barium and base-metal mineralization associated with the southern margin of the Solway - Northumberland Trough. Conference Report. Transactions of the Institution of Mining and Metallurgy, 101, B171-B172. 


\section{Figures}

Fig. 1 Geological map of the northern Pennine area. A = Acorn Sike (Polygenetic Conglomerate); D = Dufton Microgranite; GSV = Great Sulphur Vein; HB = Haydon Bridge mining area; PL = Pike Law; RF = Rotherhope Fell; RV = Rookhope Red Vein; SV = Slitt Vein; WV = Hunstanworth White Vein.

Fig. 2 Observed Bouguer gravity anomalies in the North Pennine region. Based on stations from the British Geological Survey national gravity databank. Contour interval $=2 \mathrm{mGal}$. Dashed line is the edge of the fluorite zone (after Dunham 1990). Grey shading indicates urban areas; black dots are selected boreholes.

Fig. 3 Depth to the top of the Caledonian basement in km below sea level (after Chadwick et al. 1995). Dark grey shaded areas indicated where this surface is faulted.

Fig. 4 (a) Gravity field after removal of the effects of the post-Caledonian sedimentary rocks. (b) Assumed long-wavelength regional gravity variation. (c) Gravity field after removal of effects due to sediments and regional field; used as input to modelling. (d) Calculated gravity field due to granite body illustrated in Fig. 5. Contours are at $2 \mathrm{mGal}$ intervals.

Fig. 5 Depth to the top of the North Pennine granite batholith (in km below sea level), based on $3 \mathrm{D}$ gravity modelling. The granite has been assumed to have a density contrast of -0.15 $\mathrm{Mg} / \mathrm{m}^{3}$ with the country rock and a flat base lying at a depth of $9 \mathrm{~km}$ below sea level. $\mathrm{HB}=$ Haydon Bridge mining area.

Fig. 6 Alternative model for the depth to the top of the granite (in km below sea level), assuming that its base lies at a depth of $12 \mathrm{~km}$ and the density contrast is $-0.125 \mathrm{Mg} / \mathrm{m}^{3}$.

Fig. 7 Unmigrated seismic reflection section over the central part of line BGS86-03 (see Fig. 5 for location).

Fig. 8 Detail of the shallow part of line BGS86-03 (migrated stack) with the top granite surfaces from alternative 3D gravity models superimposed. The modelled surfaces have been converted to two-way travel time assuming seismic velocities of $4 \mathrm{~km} / \mathrm{s}$ for the Carboniferous rocks and $5.5 \mathrm{~km} / \mathrm{s}$ for the underlying basement.

Fig. 9 Seismic reflection data from line BGS86-04. (a) Line drawing for the top $6 \mathrm{~s}$ of the full profile, based on migrated data in the shallow section and unmigrated data at depth (after Evans et al. 1988). Top granite surfaces from alternative 3D gravity models have been 
converted to two-way travel time assuming seismic velocities of $4 \mathrm{~km} / \mathrm{s}$ for the Carboniferous rocks and $5.5 \mathrm{~km} / \mathrm{s}$ for the underlying basement. (b) Detail of reflectivity within the granite in the western part of the section (migrated stack).

Fig. 10 Magnetic anomalies over the North Pennine batholith. (a) Reduced-to-pole magnetic field; (b) The same field after upward continuation by 2 km; (c) Residual anomalies calculated by subtracting (b) from (a). Colour shaded-relief images with vertical illumination. The model contours from Figure 5 are superimposed on each image. Many of the shorter wavelength magnetic anomalies in (c) are due to disruption of the Whin Sill, but the Blanchland anomaly on the northern side of the Weardale Pluton and possible analogues on the flanks of this and the other plutons are more likely to relate to effects within the basement.

Fig. 11 U-Pb concordia diagram for sample FMM-164 (Weardale Granite Pluton from Rookhope Borehole depth $418 \mathrm{~m}$ ). Error ellipses shown at $2 \sigma$ level, including decay constant errors. Concordia age calculated from fractions Z4 and Z11 shown as ellipse with dashed line. Inset illustrates representative zircon fractions analysed (post chemical abrasion stage), scale bar is $200 \mu \mathrm{m}$.

Fig. 12 Model of granite thickness in the northern England region (after Kimbell et al. 2006)

Fig. 13 Seismic reflection section (migrated stack) across the edge of the Lake District batholith (after Chadwick et al. 2005). For location see Figure 12. Unreflective sheets of granite are interpreted to be interleaved with reflective layers of country rock (and/or sills). $\mathrm{EnG}=$ Ennerdale Microgranite Pluton; EsG = Eskdale Granite Pluton. Black dashed line is the approximate envelope of the batholith.

Table 1. Summarized litho-and chrostratigraphy of the Alston Block and its environs. The densities assumed in the gravity modelling (final column) are from Kimbell et al. (2006). Formations within the Great Scar Limestone, Ravenstonedale and Inverclyde groups are not shown; for further detail of these see Stone et al. (2010) and Waters et al. (2007).

Table 2. U-Pb zircon data (ID-TIMS) for sample FMM-164 (Weardale Granite Pluton from Rookhope Borehole depth $418 \mathrm{~m}$ ). 
Table 1. Summarized litho-and chronostratigraphy of the Carboniferous strata of the Alston Block and its environs. The densities assumed in the gravity modelling (final column) are from Kimbell et al. (2006). Formations within the Great Scar Limestone, Ravenstonedale and Inverclyde groups are not shown; for further detail of these see Stone et al. (2010) and Waters et al. (2007).

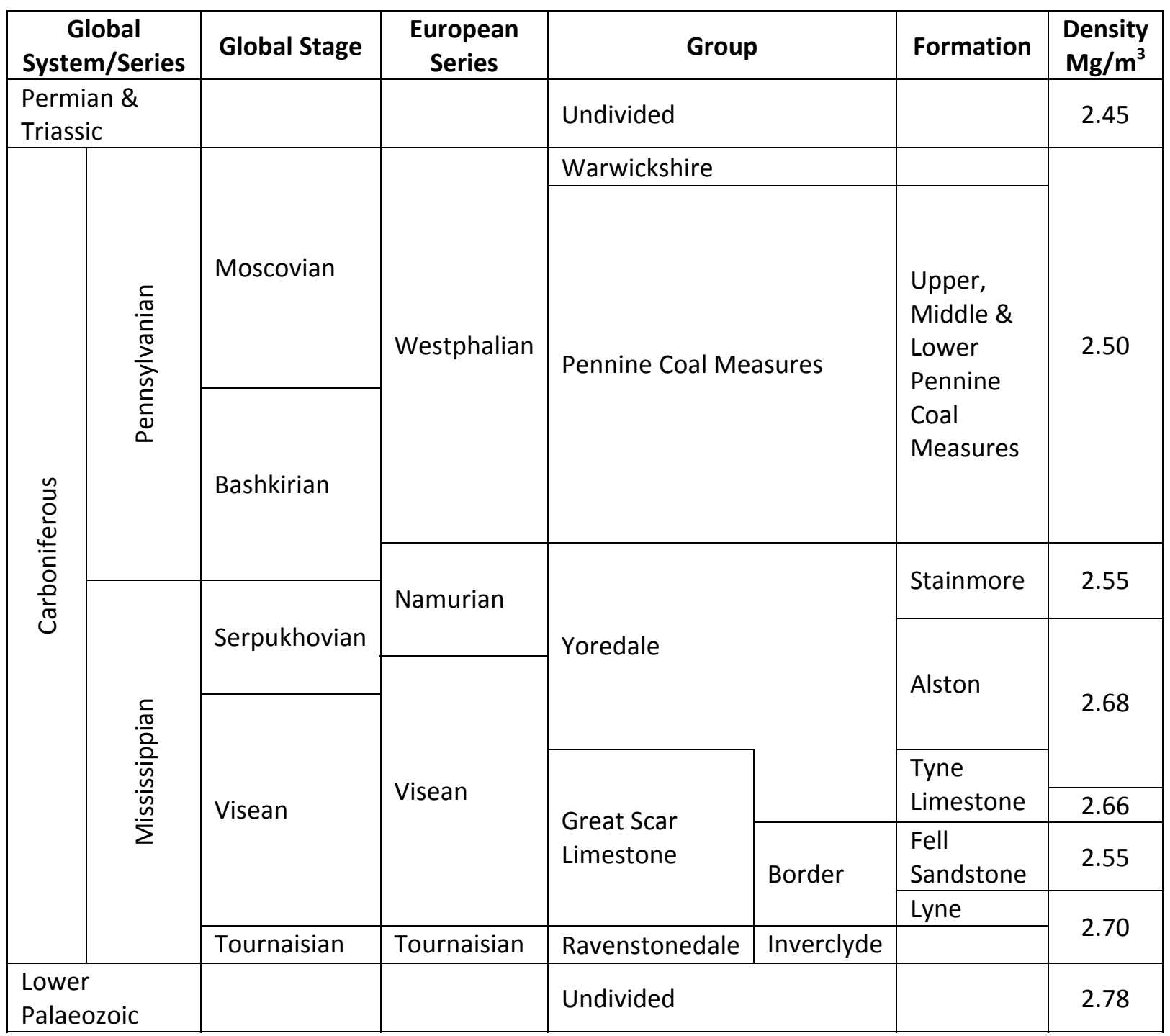


Table 2. U-Pb zircon data (ID-TIMS) for sample FMM-164 (Weardale Granite Pluton from Rookhope Borehole depth $418 \mathrm{~m}$ ).

\begin{tabular}{|c|c|c|c|c|c|c|c|c|c|c|c|c|c|c|}
\hline \multirow[t]{2}{*}{ Fraction } & \multirow{2}{*}{$\begin{array}{c}\text { Weight } \\
(\mu \mathrm{g})\end{array}$} & \multirow{2}{*}{$\begin{array}{c}\mathbf{U} \\
(\mathrm{ppm})\end{array}$} & \multirow{2}{*}{$\begin{array}{l}\text { Cm-Pb } \\
(\mathrm{ppm})^{\ddagger}\end{array}$} & \multicolumn{8}{|c|}{ Ratios } & \multicolumn{3}{|c|}{ Ages (Ma) } \\
\hline & & & & ${ }^{206} \mathrm{~Pb} /{ }^{204} \mathrm{~Pb}^{\dagger}$ & ${ }^{207} \mathrm{~Pb} /{ }^{206} \mathrm{~Pb}^{*}$ & $2 \sigma \%$ & ${ }^{206} \mathrm{~Pb} /{ }^{238} \mathrm{U}^{*}$ & $2 \sigma \%$ & ${ }^{207} \mathrm{~Pb} /{ }^{235} \mathrm{U}^{*}$ & $2 \sigma \%$ & Rho & ${ }^{207} \mathrm{~Pb} /{ }^{206} \mathrm{~Pb}$ & ${ }^{206} \mathrm{~Pb} /{ }^{238} \mathrm{U}$ & ${ }^{207} \mathrm{~Pb} /{ }^{235} \mathrm{U}$ \\
\hline$Z-2$ & 1.6 & 161 & 0.80 & 1304 & 0.05474 & 0.17 & 0.06364 & 0.22 & 0.48031 & 0.28 & 0.78 & 401.5 & 397.7 & 398.3 \\
\hline Z-3 & 1.0 & 282 & 1.68 & 681 & 0.05471 & 0.33 & 0.06316 & 0.22 & 0.47643 & 0.40 & 0.58 & 400.5 & 394.8 & 395.6 \\
\hline Z-4 & 1.0 & 342 & 2.36 & 600 & 0.05466 & 0.30 & 0.06396 & 0.20 & 0.48204 & 0.37 & 0.59 & 398.5 & 399.6 & 399.5 \\
\hline Z-5 & 1.0 & 172 & 1.54 & 464 & 0.05459 & 0.56 & 0.06360 & 0.28 & 0.47867 & 0.64 & 0.50 & 395.3 & 397.5 & 397.2 \\
\hline Z-7 & 2.2 & 217 & 0.16 & 12321 & 0.05469 & 0.14 & 0.06383 & 0.24 & 0.48135 & 0.28 & 0.86 & 399.6 & 398.9 & 399.0 \\
\hline Z-8 & 0.8 & 667 & 0.88 & 2355 & 0.05494 & 0.09 & 0.06122 & 0.16 & 0.46379 & 0.19 & 0.88 & 409.9 & 383.0 & 386.9 \\
\hline Z-9 & 2.3 & 641 & 1.06 & 5554 & 0.05474 & 0.11 & 0.06356 & 0.18 & 0.47968 & 0.21 & 0.86 & 401.5 & 397.2 & 397.9 \\
\hline Z-10 & 2.3 & 497 & 0.64 & 7005 & 0.05489 & 0.09 & 0.06194 & 0.17 & 0.46877 & 0.19 & 0.89 & 407.8 & 387.4 & 390.3 \\
\hline$Z-11$ & 0.8 & 368 & 1.76 & 685 & 0.05476 & 0.20 & 0.06364 & 0.18 & 0.48049 & 0.28 & 0.68 & 402.3 & 397.7 & 398.4 \\
\hline
\end{tabular}

All errors are $2 \sigma$ (per cent for ratios, absolute for ages)

t Total common $\mathrm{Pb}$ in analysis, corrected for spike and fractionation $(0.05 \% / \mathrm{amu})$

$\uparrow$ Measured ratio, corrected for spike and $\mathrm{Pb}$ fractionation

* Corrected for blank $\mathrm{Pb}, \mathrm{U}$ and common $\mathrm{Pb}$ (Stacey \& Kramers 1975) 


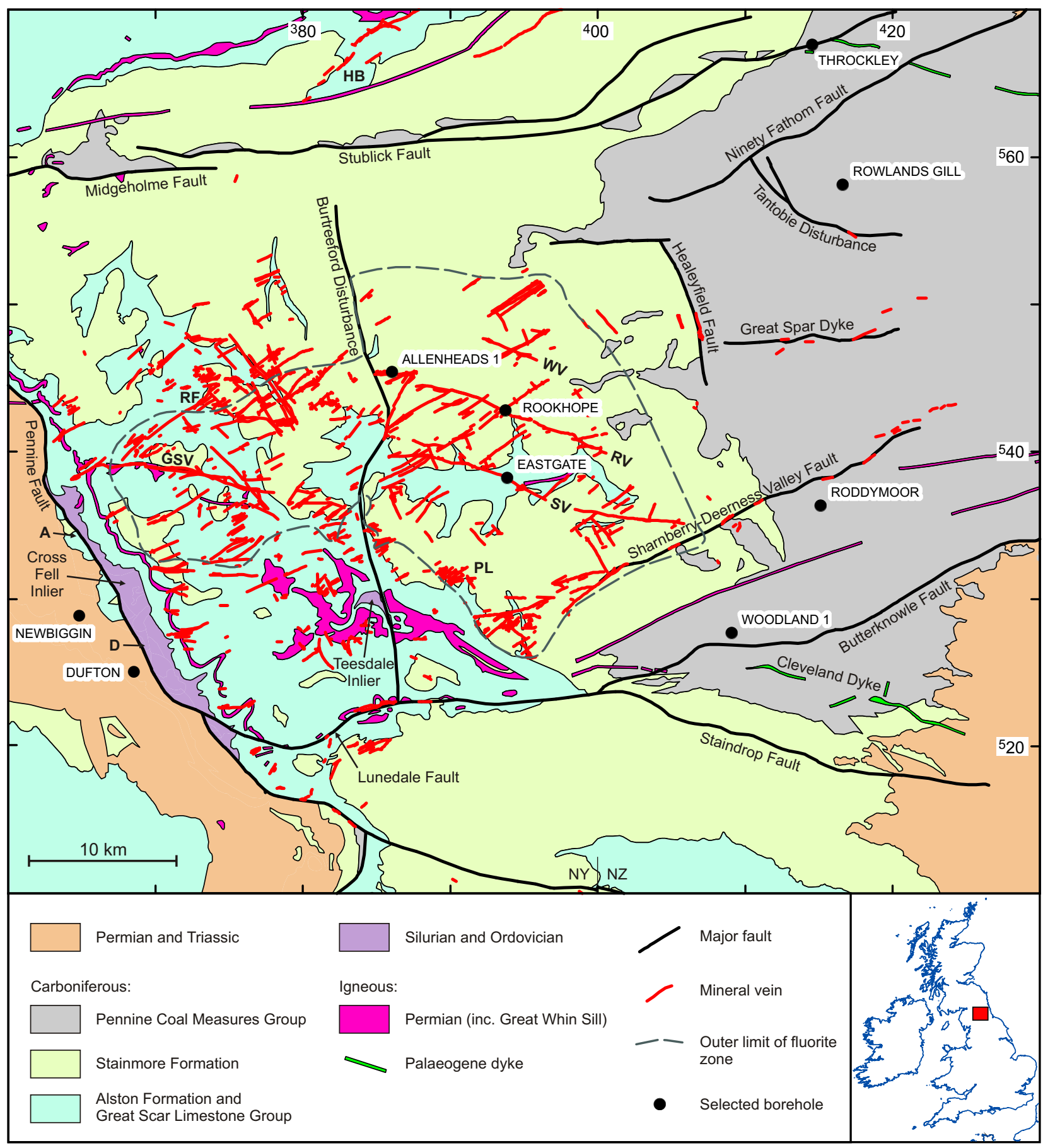

Fig. 1 


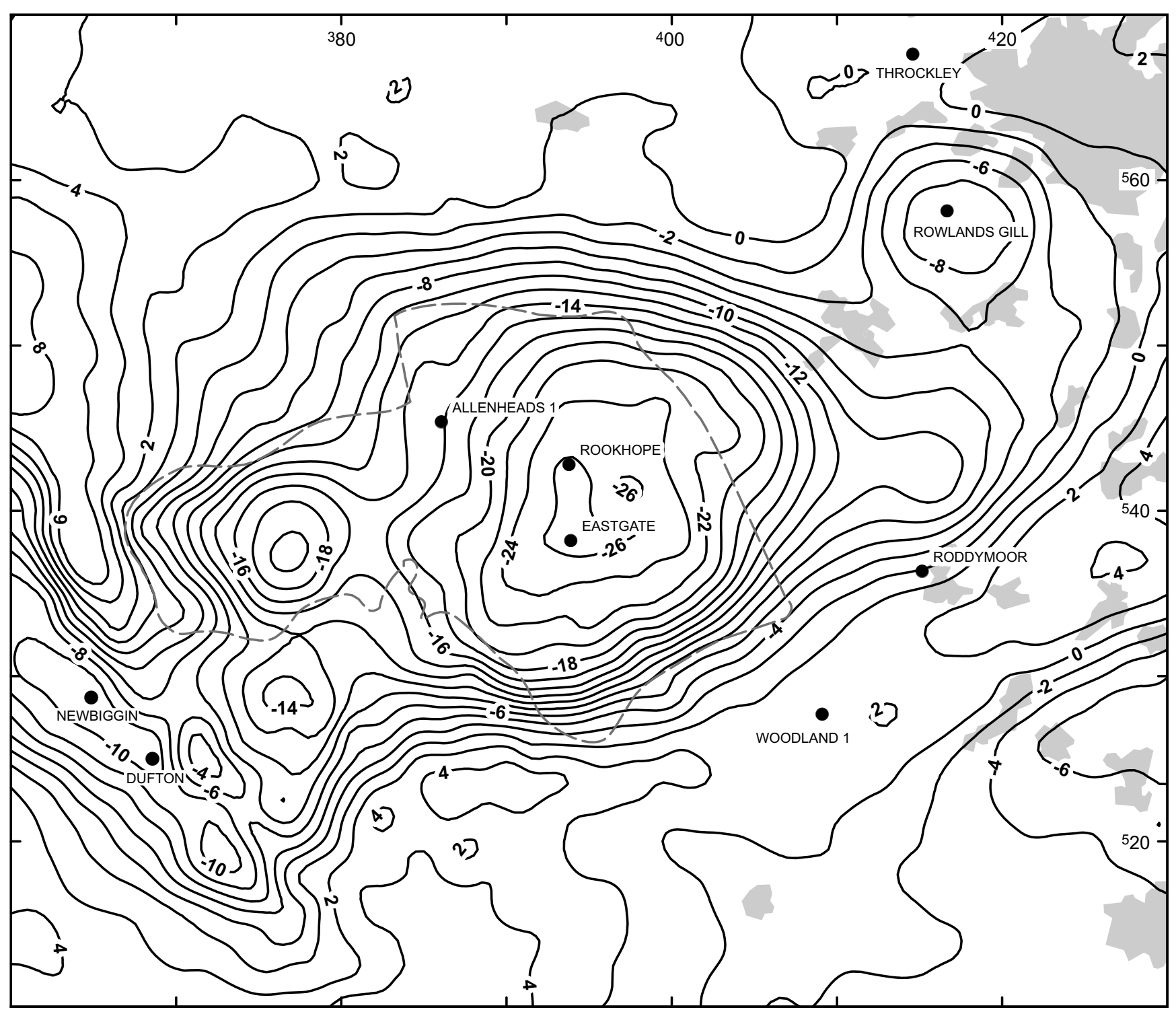

Fig. 2 


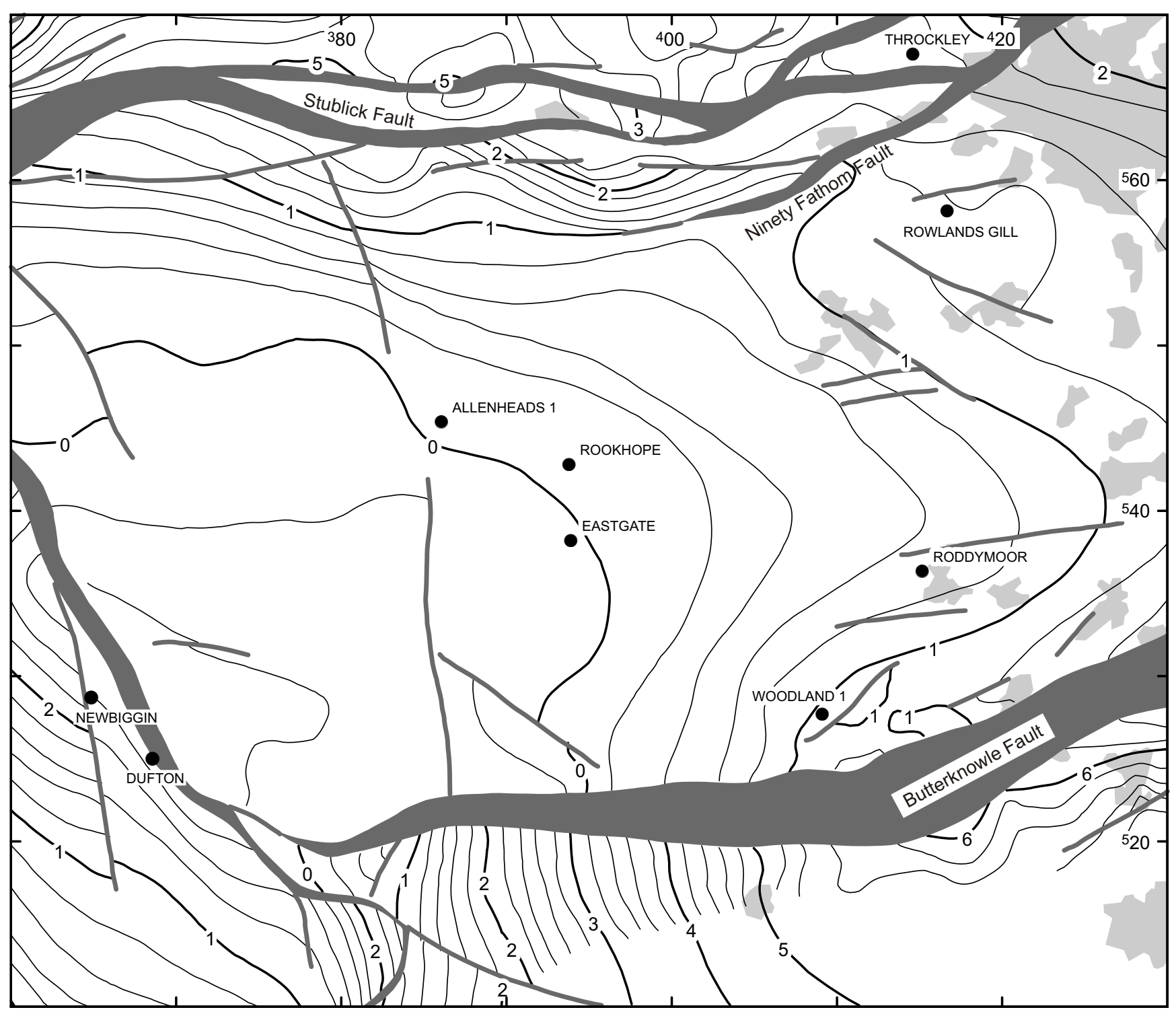

Fig. 3 

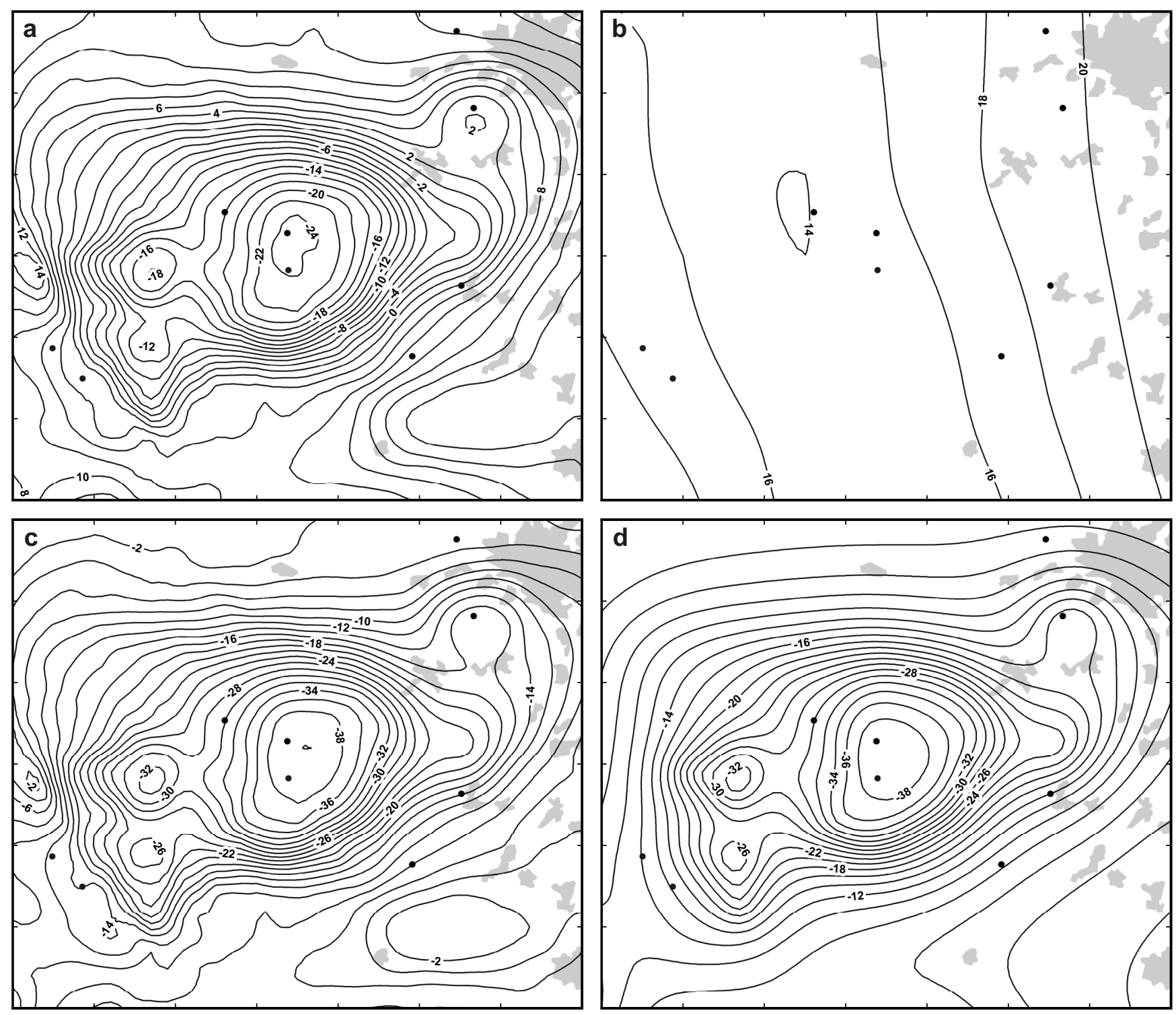

Fig. 4 


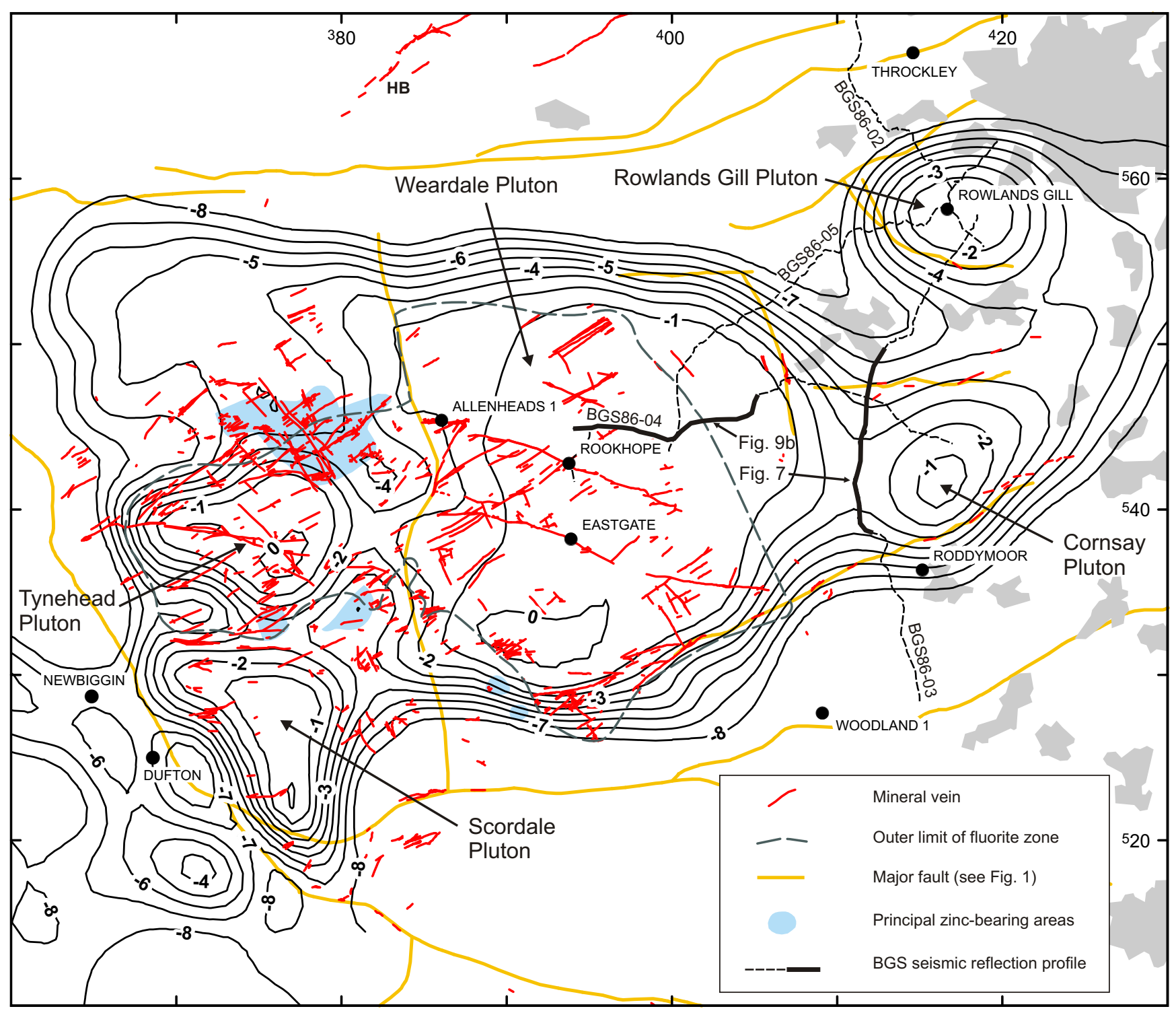

Fig. 5 


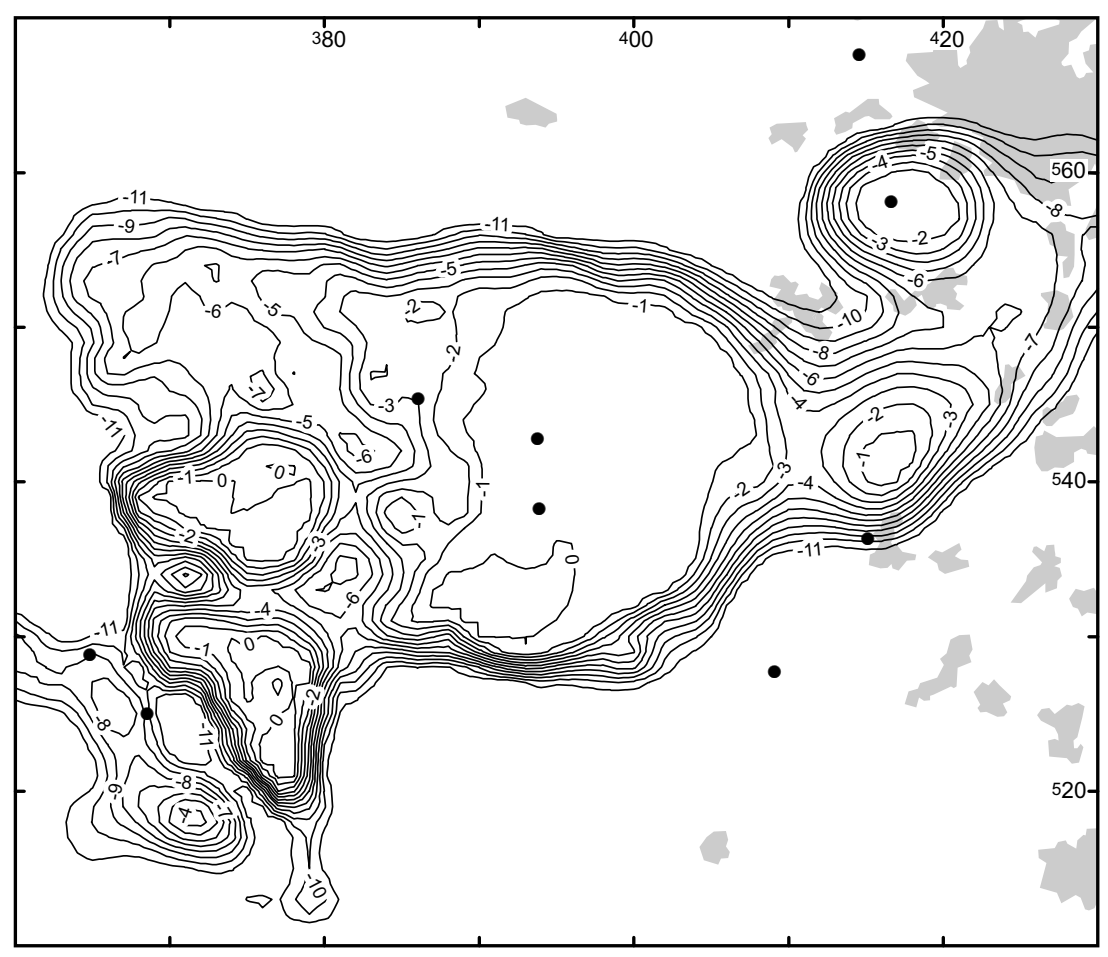

Fig. 6 
S

$5 \mathrm{~km}$

N

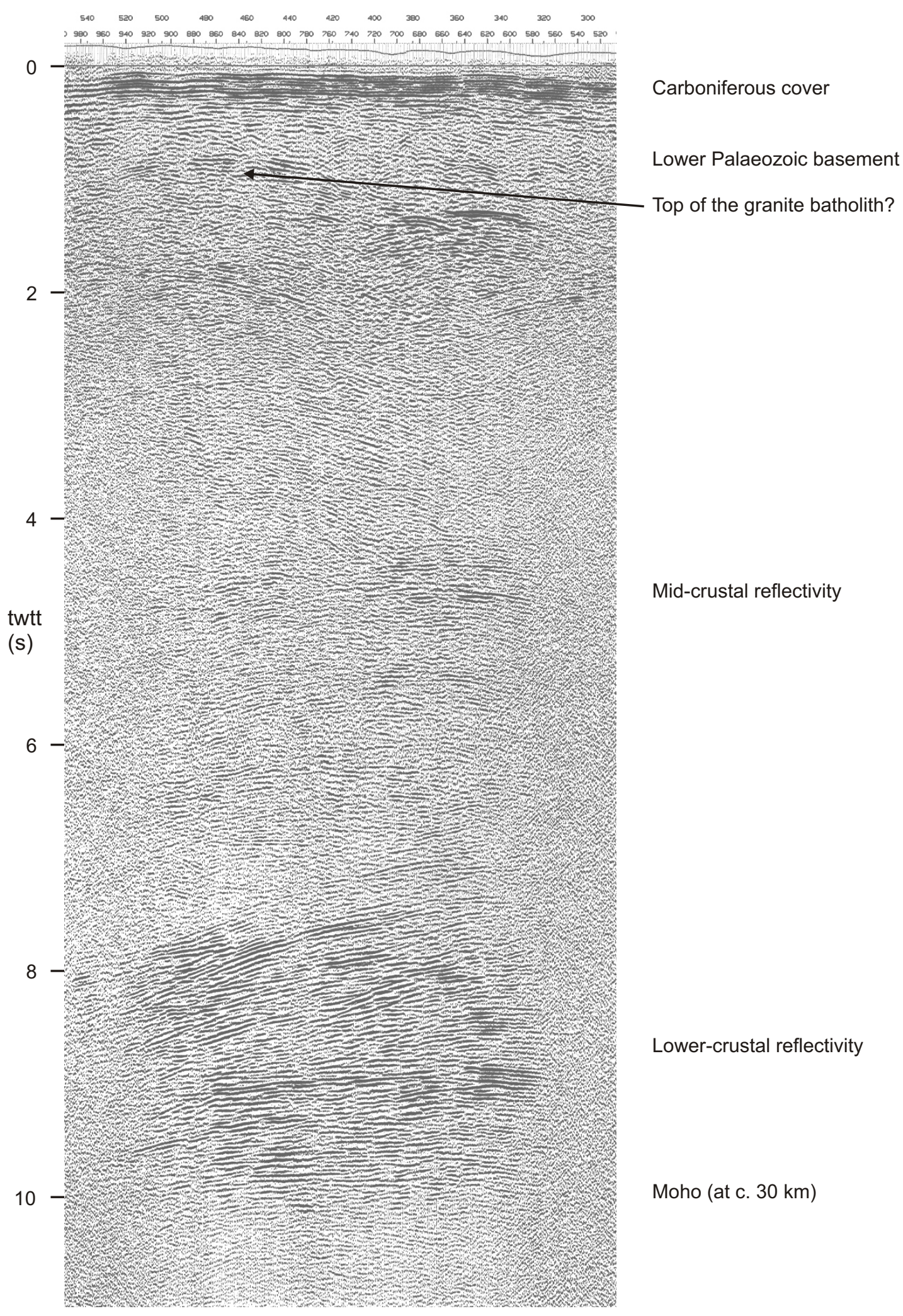

Fig. 7 
S

Hett Roddymoor Sharnberry

$\begin{array}{ll}\text { Roddymoor } & \text { Bharnoult } \\ \text { Dyke } & \text { Borehole }\end{array}$

Great Spar Dyke (Fault)

Tantobie

Disturbance

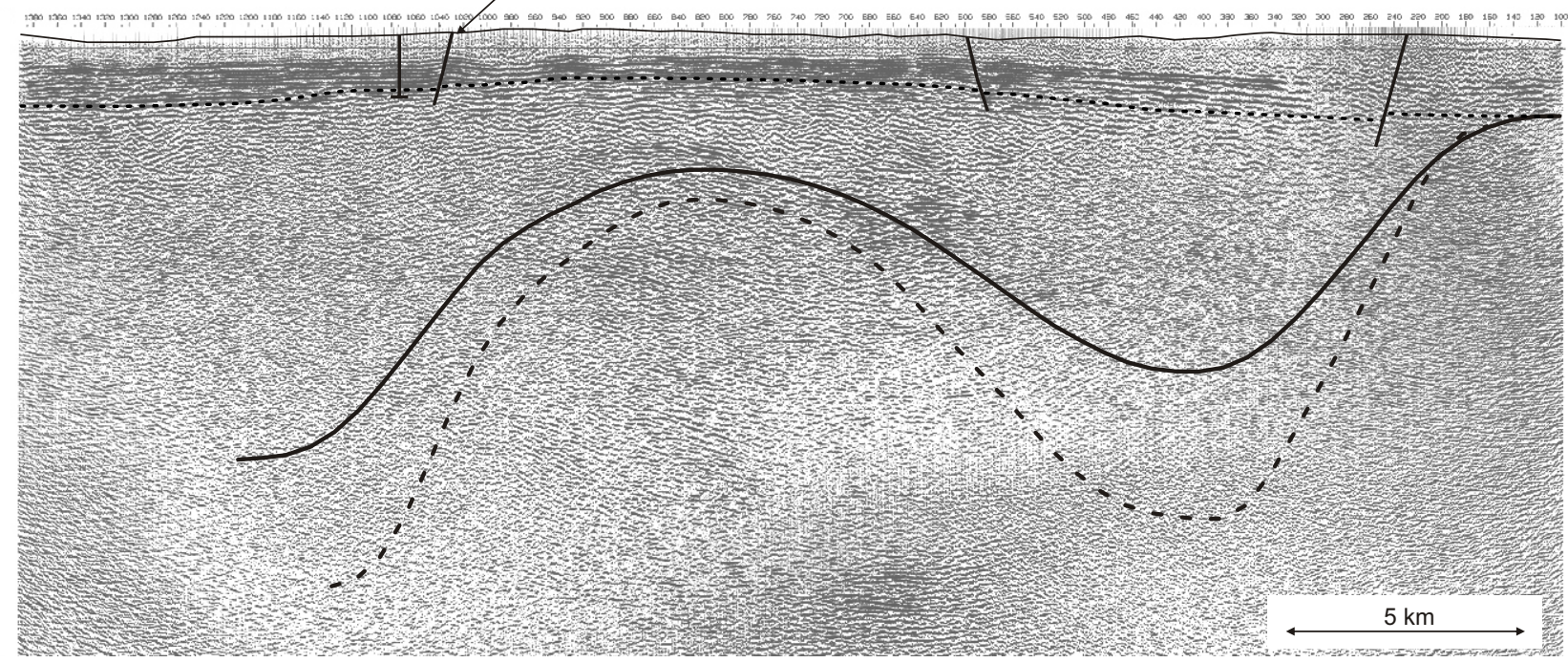

Top of Lower Palaeozoic basement: . . . .

Top of granite from 3D gravity modelling:

(base at $9 \mathrm{~km}$ )

- - - (base at $12 \mathrm{~km}$ )

Fig. 8 
(a)

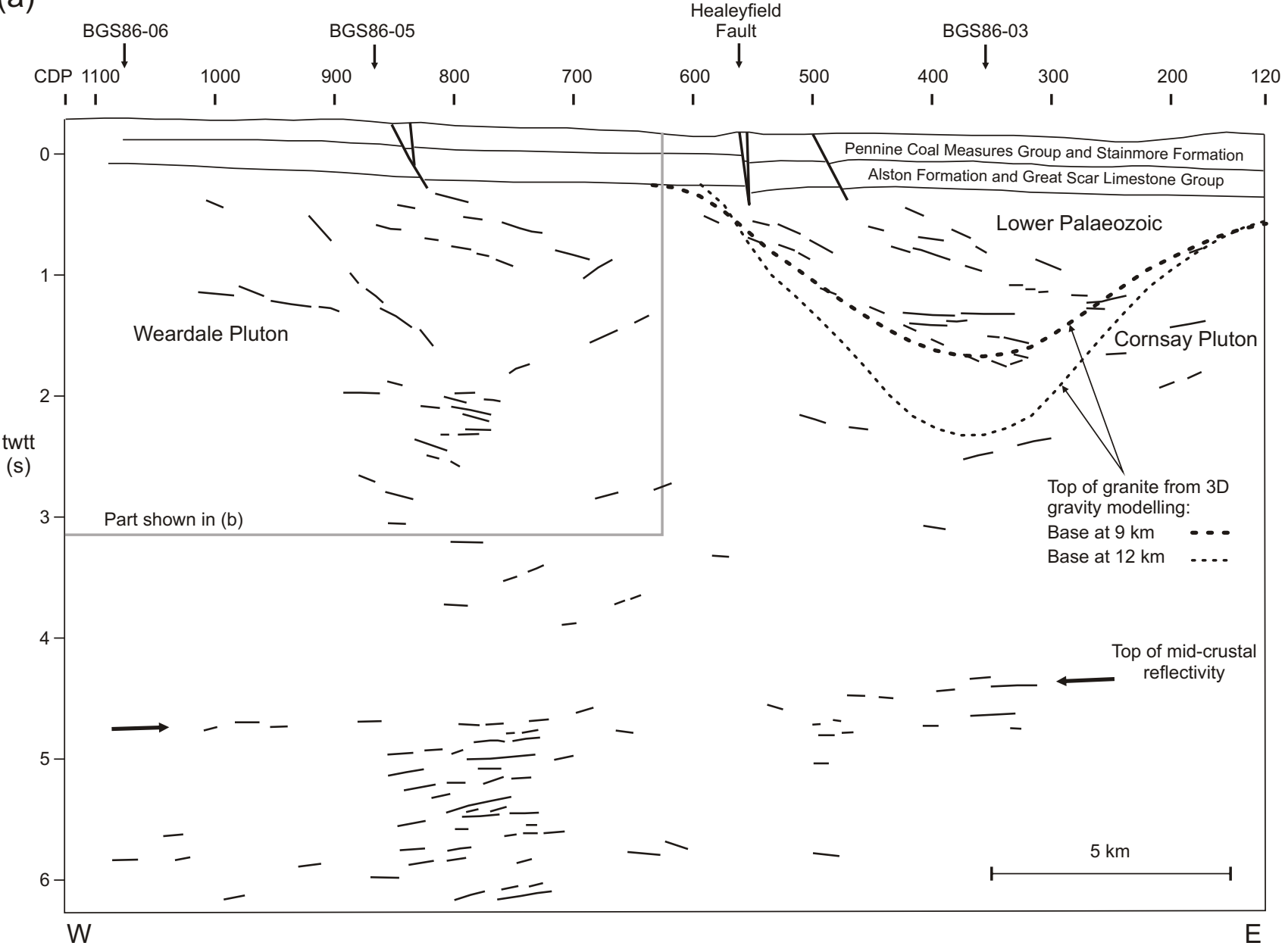

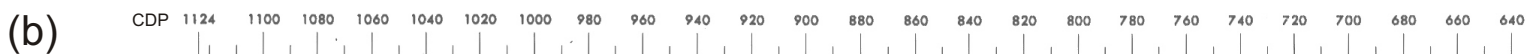

twtt

0

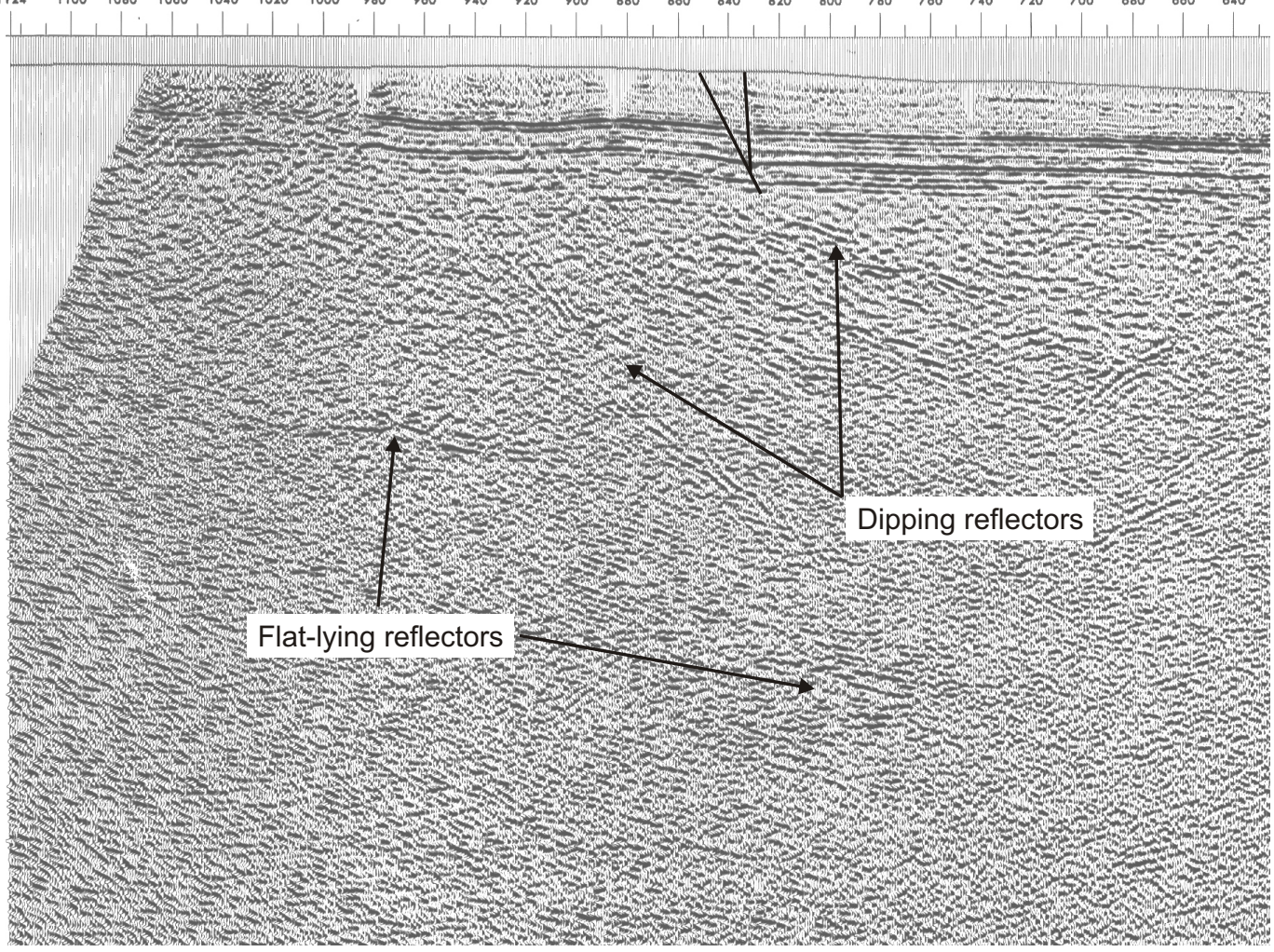

$5 \mathrm{~km}$

Fig. 9 

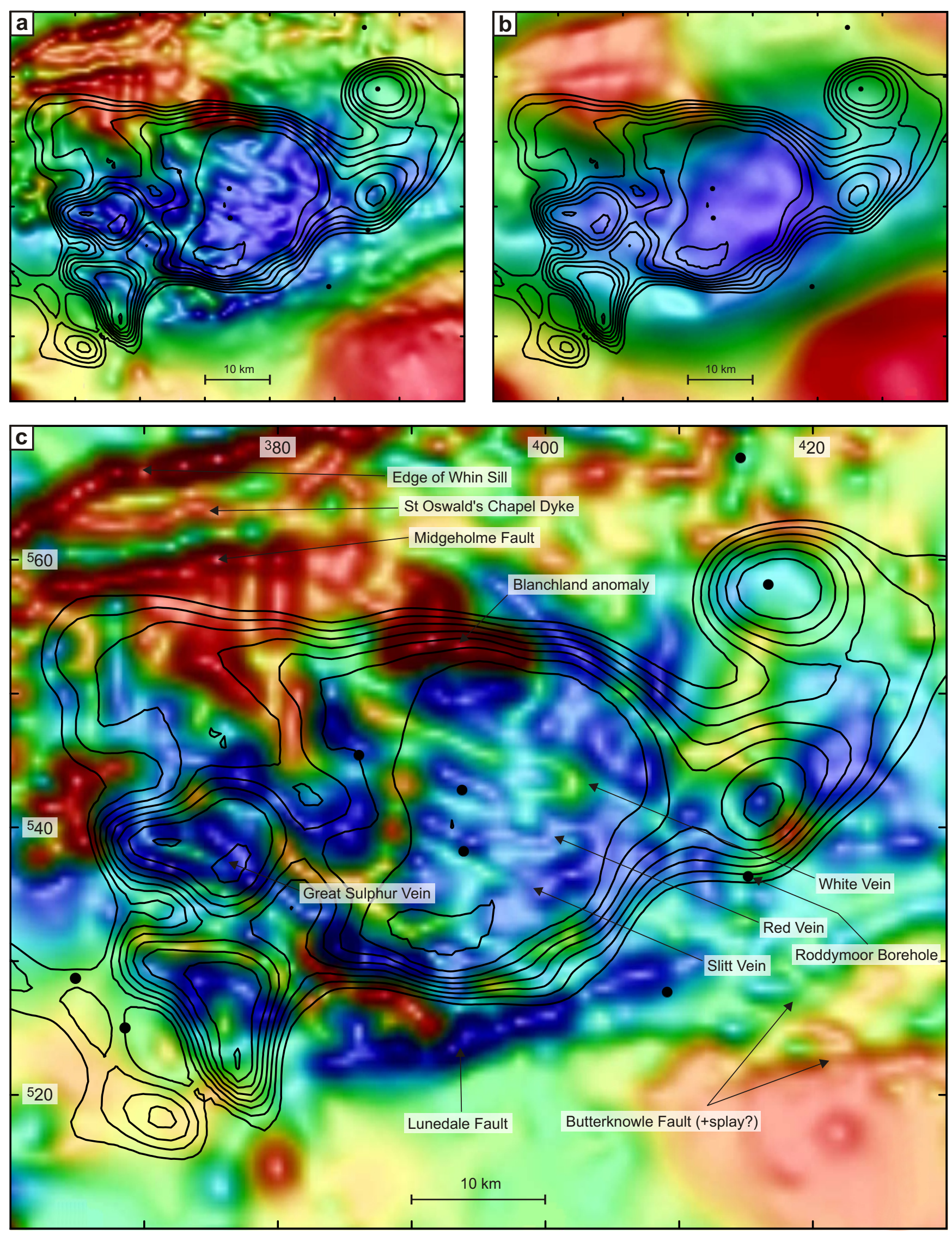

Fig. 10 


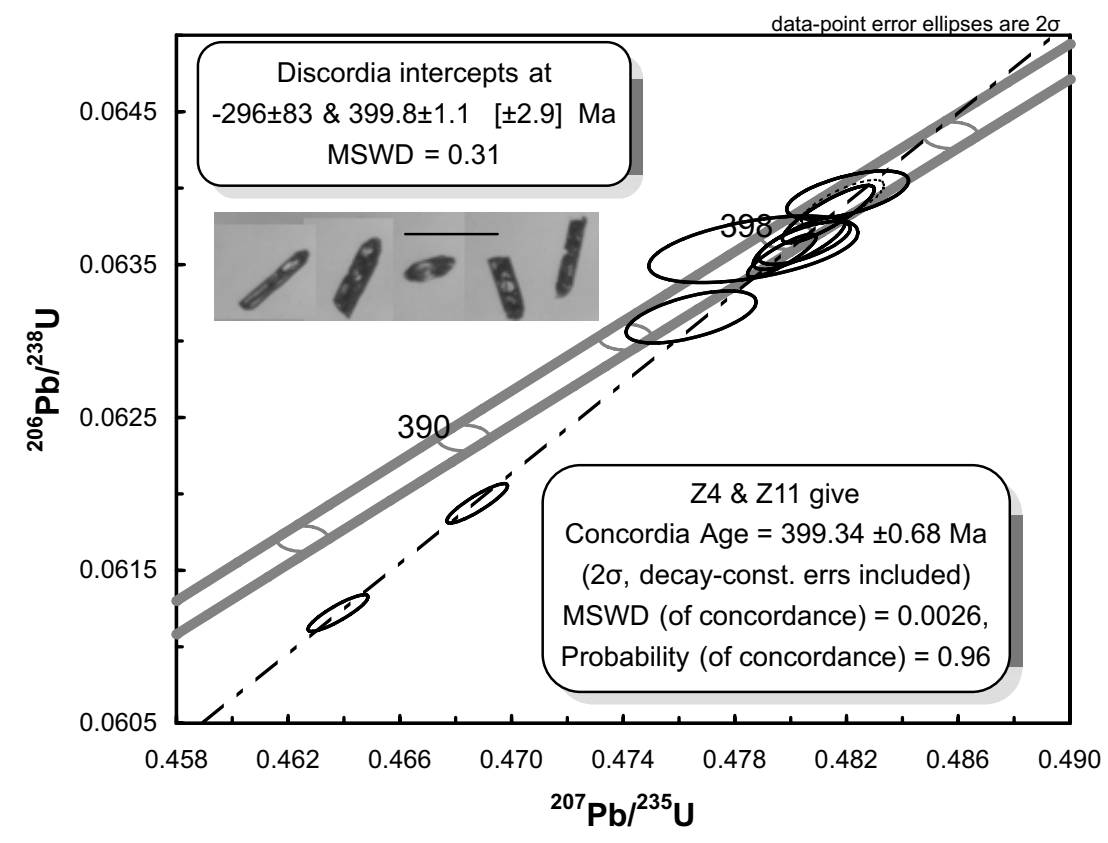

Fig. 11 


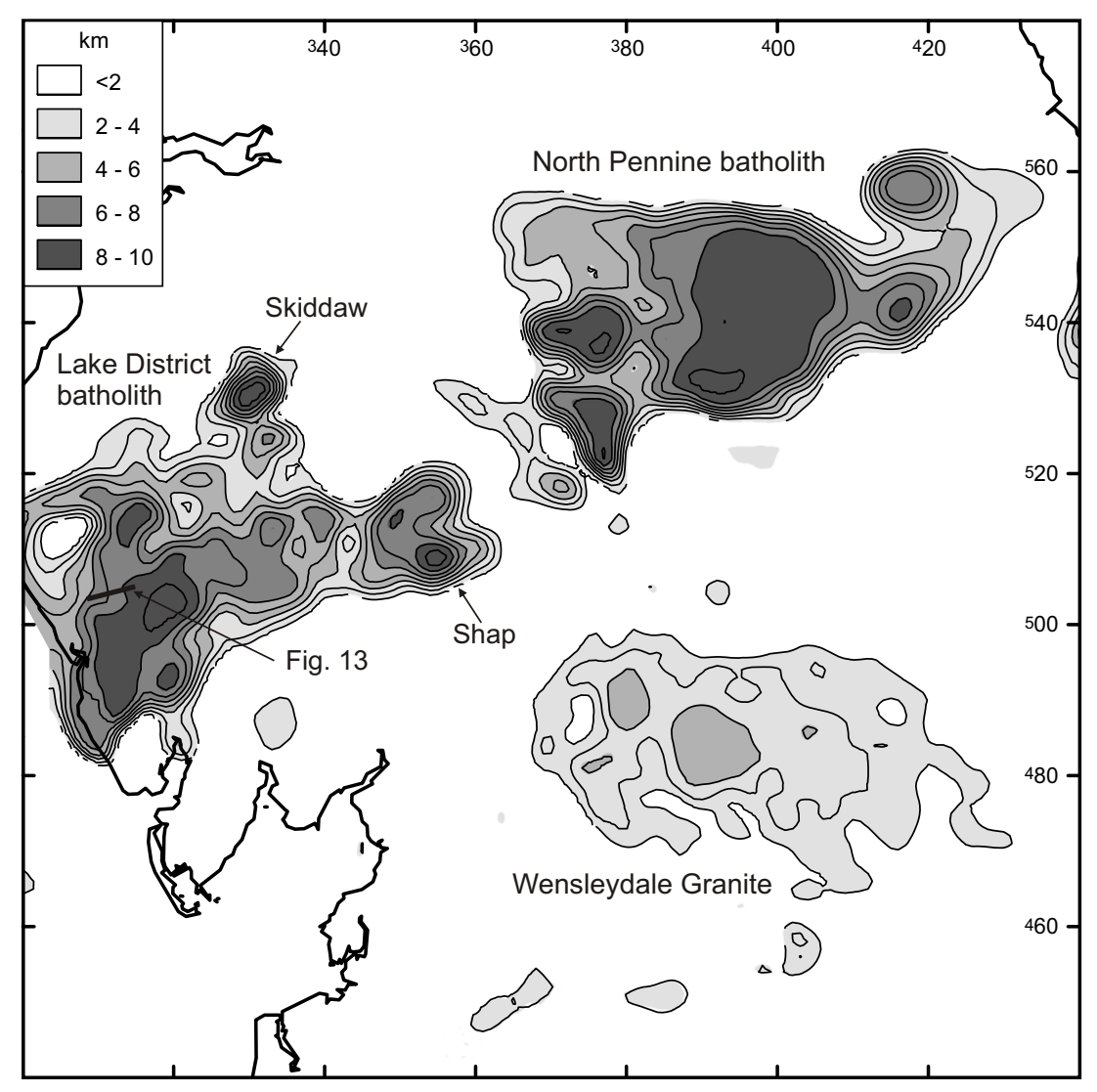

Fig. 12 


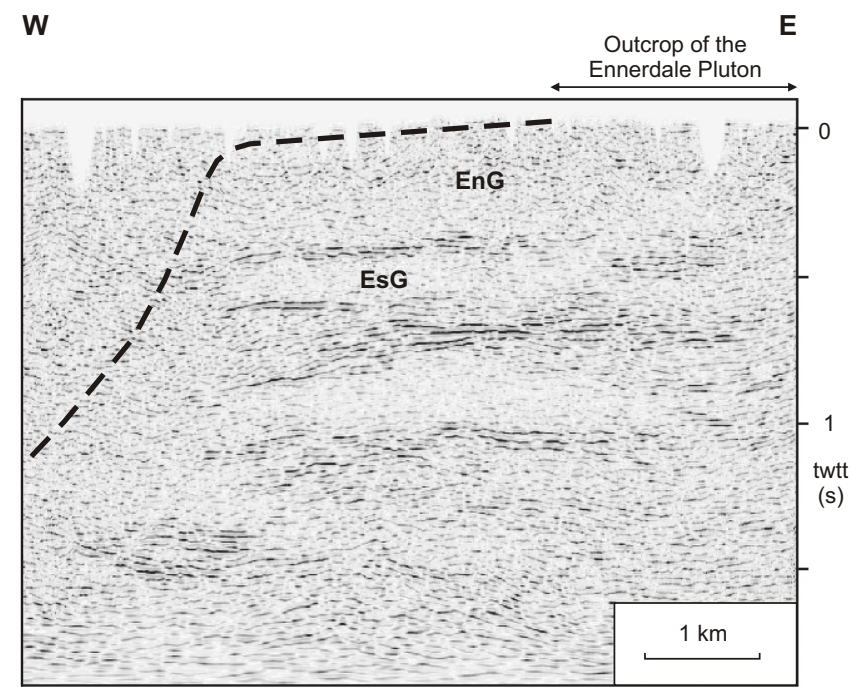

Fig. 13 